\title{
DESIGN OF EQUIPMENT USED FOR \\ HIGH-LEVEL WASTE VITRIFICATION \\ AT THE WEST VALLEY DEMONSTRATION PROJECT
}

Topical Report

By

Richard F. Vance

Bernard A. Brill

Daniel E. Carl

Hardip S. Dhingra

Aichard A. Meigs

Mark G. Studd

June 1997

Work Performed Under Contract No. AC24-81NE44139

Prepared for

U.S. Department of Energy

Assistant Secretary for Nuclear Energy

Prepared by

West Valley Nuclear Services Company, Inc. West Valley, NY 14171-0191 


\section{DISCLAMMER}

Portions of this document may be illegible in electronic image products. Images are produced from the best available original document. 



\section{TABLE OF CONTENTS}

Section

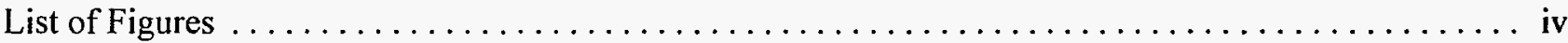

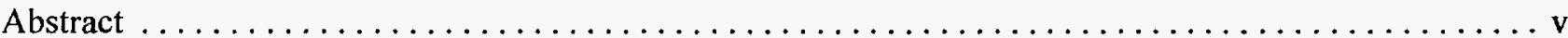

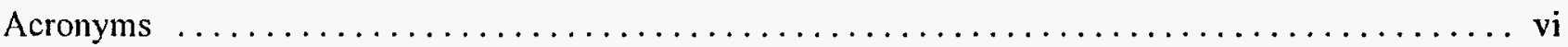

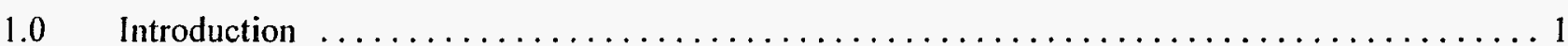

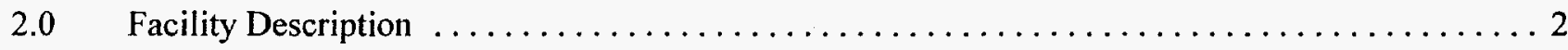

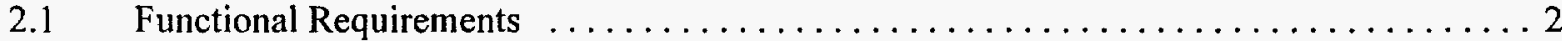

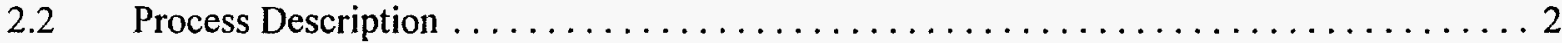

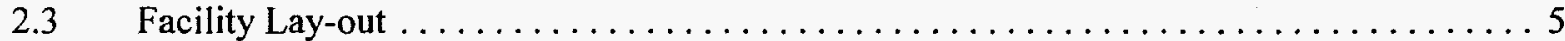

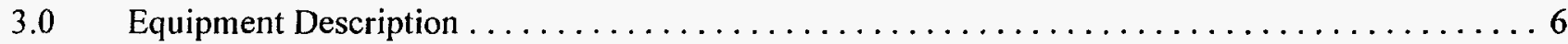

3.1 Sludge Mobilization and High-level Waste Transfer System . . . . . . . . . . . . 6

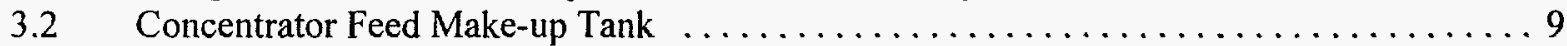

$3.3 \quad$ Slurry Sample System . . . . . . . . . . . . . . . . . . . . . . . . 12

$3.4 \quad$ Melter Feed Hold Tank . . . . . . . . . . . . . . . . . . . . . . . . . . . . . . . 14

$3.5 \quad$ Melter Feed Pump . . . . . . . . . . . . . . . . . . . . . . . . . . . . . 17

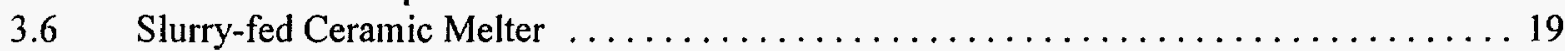

$3.7 \quad$ Canister . . . . . . . . . . . . . . . . . . . . . . . . . . . . . . . 25

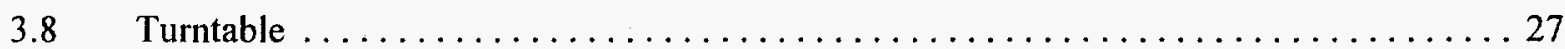

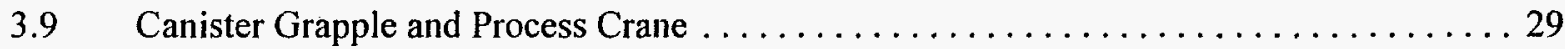

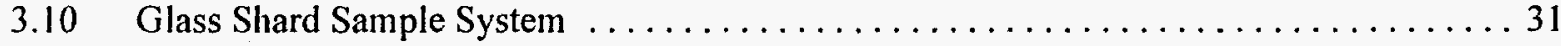

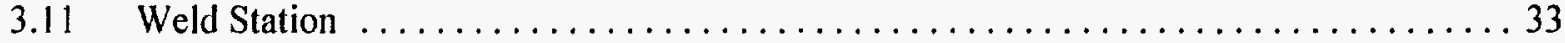

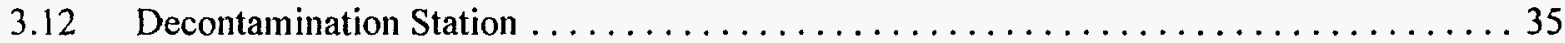

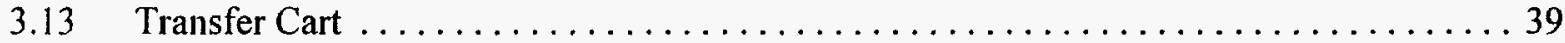

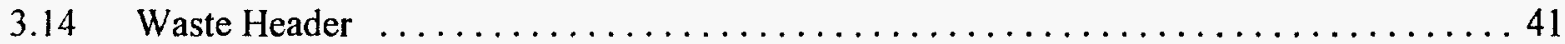



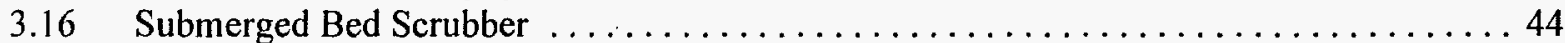

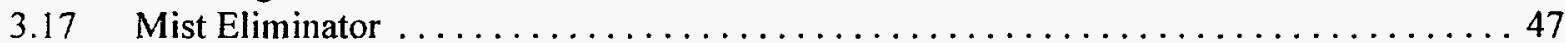

3.18 High-efficiency Mist Eliminators $\ldots \ldots \ldots \ldots \ldots \ldots \ldots \ldots \ldots \ldots \ldots \ldots \ldots \ldots \ldots \ldots$

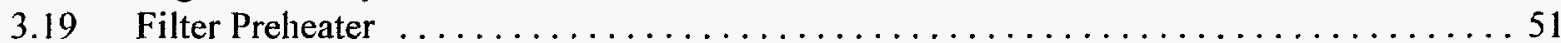

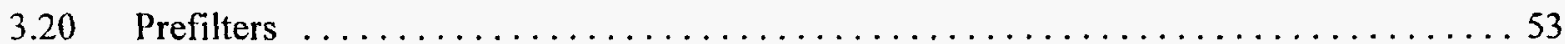

3.21 Reheater ....................................... 55

3.22 Final High-efficiency Particulate Air (HEPA) Filters $\ldots \ldots \ldots \ldots \ldots \ldots \ldots \ldots \ldots \ldots$

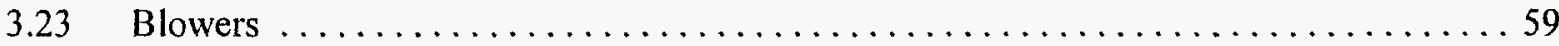

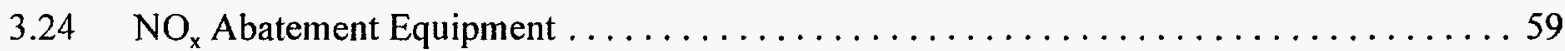

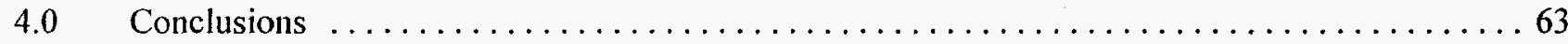

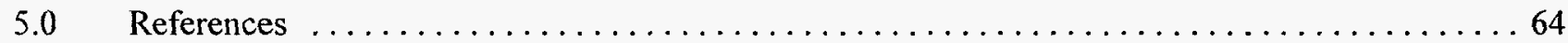

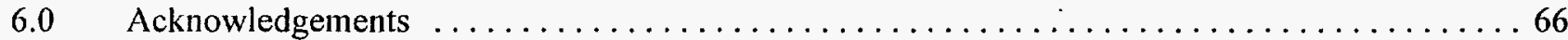




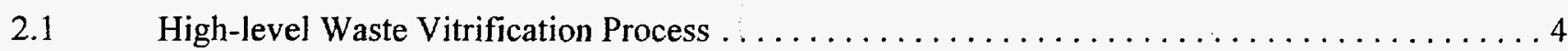

$2.2 \quad$ High-level Waste Solidification Facilities $\ldots \ldots \ldots \ldots \ldots \ldots \ldots \ldots \ldots \ldots \ldots \ldots \ldots$

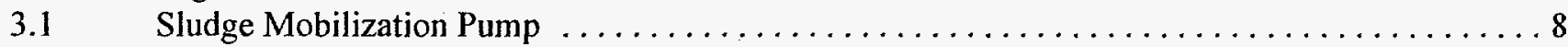

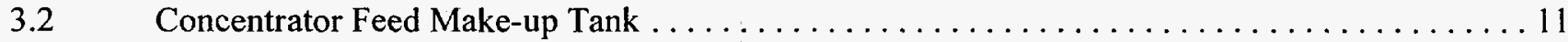

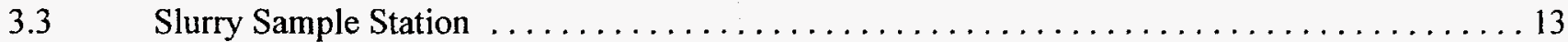

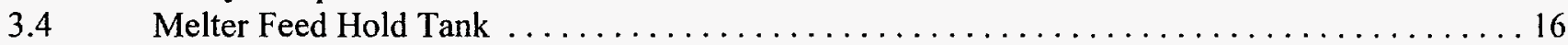

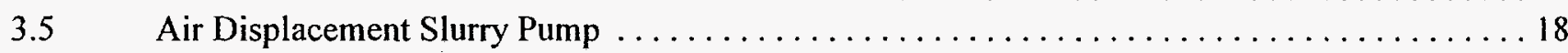

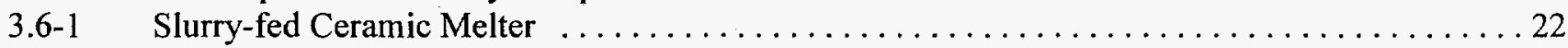

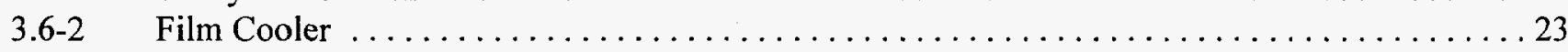

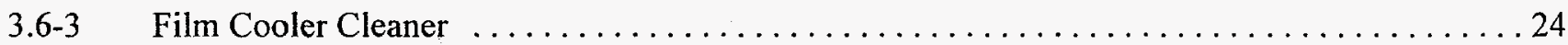

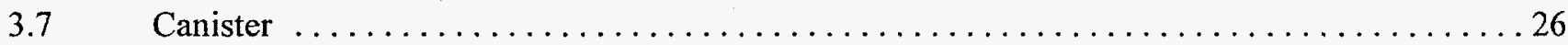

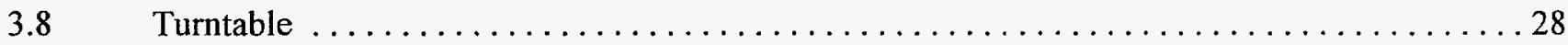

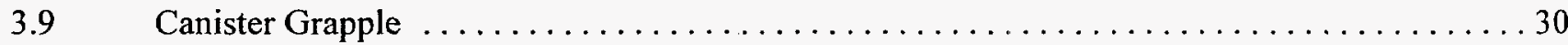

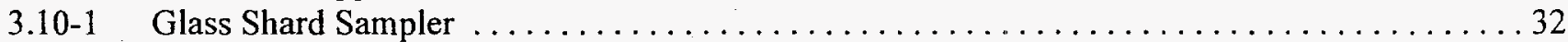

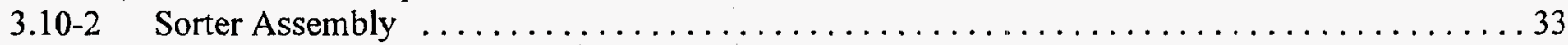

$3.11 \quad$ Weld Head . . . . . . . . . . . . . . . . . . . . . . . . . . . . . . . . . . 34

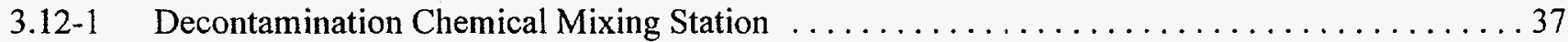

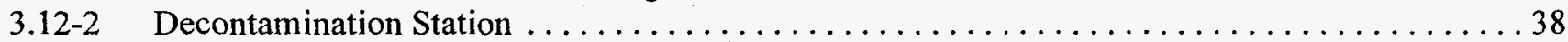

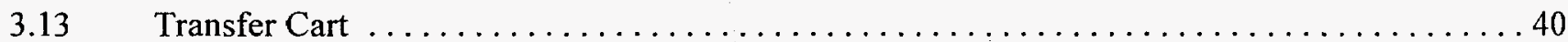

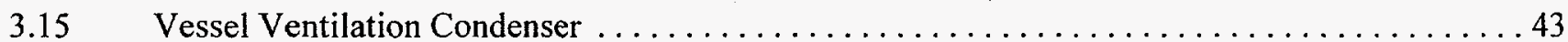

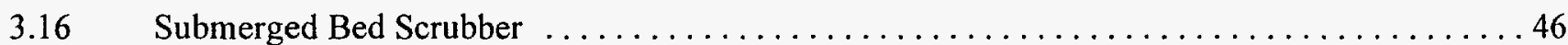

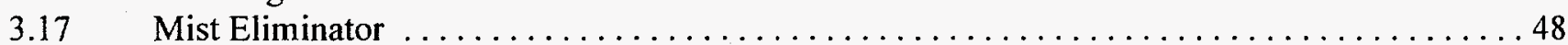

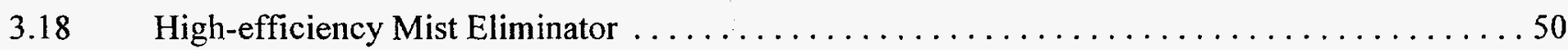

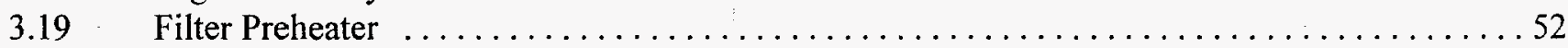

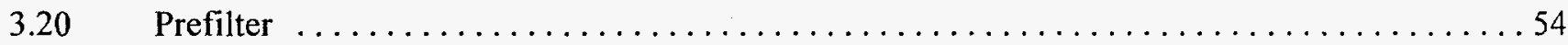

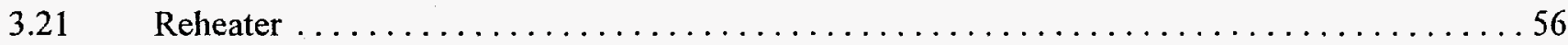

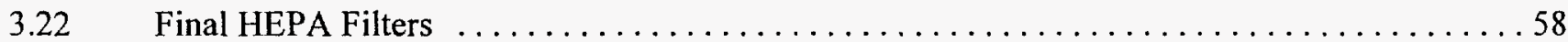

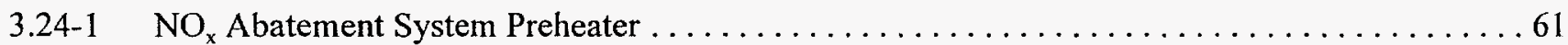

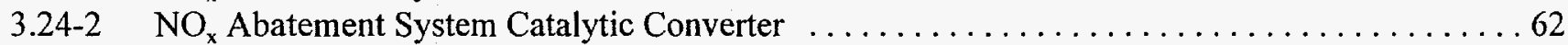




\begin{abstract}
The equipment as designed, started, and operated for high-level radioactive waste vitrification at the West Valley Demonstration Project in western New York State is described. Equipment for the processes of melter feed make-up, vitrification, canister handling, and off-gas treatment are included. For each item of equipment the functional requirements, process description, and hardware descriptions are presented.
\end{abstract}




\section{ACRONYMS}

Acronym

ADS

ALARA

ASME

CFMT

DOE

DOP

EDR

HEME

HEPA

HLW

HLWIS

HLWISF

ILDS

MFHT

PUREX

SBS

SFCM

STS

THOREX

WNYNSC

WVDP

WVNS

\section{Meaning}

Air Displacement Slurry

As Low As Reasonably Achievable

American Society of Mechanical Engineers

Concentrator Feed Makeup Tank

Department of Energy

Dioctyl phthalate

Equipment Decontamination Room

High-efficiency Mist Eliminator

High-efficiency Particulate Air Filter

High-level Radioactive Waste

High-level Waste Interim Storage

High-level Waste Interim Storage Facility

Infrared Level Detection System

Melter Feed Hold Tank

Plutonium Uranium Extraction

Submerged Bed Scrubber

Slurry-fed Ceramic Melter

Supernatant Treatment System

Thorium Extraction

Western New York Nuclear Service Center

West Valley Demonstration Project

West Valley Nuclear Services Company, Incorporated 


\subsection{INTRODUCTION}

The nuclear fuel reprocessing plant at West Valley near Buffalo, NY, was constructed in 1966. After reprocessing $640 \mathrm{Mg}$ (700 tons) of spent nuclear fuel, operations stopped in 1972.

About $2,300 \mathrm{~m}^{3}(600,000$ gal.) of high-level liquid plutonium uranium extraction (PUREX) process waste was neutralized with sodium hydroxide and stored in an underground carbon steel tank. A sludge, mostly ferric hydroxide, precipitated. The primary radioactive isotope in the liquid was ${ }^{1.77} \mathrm{Cs}$. The other radioactive isotopes, mostly ${ }^{90} \mathrm{Sr}$, became part of the sludge. The liquid and sludge each contained about $590 \mathrm{PBq}(16 \mathrm{x}$ $\left.10^{6} \mathrm{Ci}\right)$ of activity.

A reprocessing campaign for fuel that contained thorium produced $30 \mathrm{~m}^{3}(8,000$ gal. $)$ of acidic thorium extraction (THOREX) process waste which was stored in an underground stainless steel tank. It contained 70 $\operatorname{PBq}\left(2 \times 10^{6} \mathrm{Ci}\right)$ of activity.

The West Valley Demonstration Project (WVDP) was established in 1980 by Congress ${ }^{(1)}$ as a U.S. Department of Energy (DOE) high-level radioactive waste management project to be conducted at the Western New York Nuclear Service Center (WNYNSC) in West Valley, NY. The mission of the project was to demonstrate solidification techniques that could be used to prepare high-level radioactive waste (HLW) for transportation to, and disposal at, a federal repository. The DOE contracted with West Valley Nuclear Services Company, Inc. (WVNS), a subsidiary of the Westinghouse Electric Corporation, to manage the project. During July 1983 , the DOE formally selected borosilicate glass as the final waste form. ${ }^{(2)}$

This report briefly describes the process, the facility, and the equipment used to vitrify the HLW. It addresses those items of equipment directly involved with processing the radioactive waste.

Because this report presents final designs, it effectively supercedes a topical report on the same subject that was prepared during the conceptual design period of the project. ${ }^{(3)}$ 


\subsection{FACILITY DESCRIPTION}

\subsection{Functional Requirements}

The goal of the system design is to process the HLW into borosilicate glass in a period of approximately 30 months after start-up of the Vitrification Facility.

Vitrification Facility functional requirements, pertinent to the equipment described in this report, are specified in the controlling design criteria document for the Vitrification Facility ${ }^{(4)}$, and are as follows:

- Process the HLW in melter feed preparation equipment by mixing the HLW with other glass formers and chemicals. Evaporate the excess water for delivery to the vitrification equipment.

- Provide a method for moving the melter feed from the preparation equipment to the vitrification equipment.

- Vitrify the melter feed into borosilicate glass, which is the selected final waste form.

- Move the canisters in and out from underneath the melter pour spout(s) and hold the canister while the glass is being poured into it. Also, move the canisters into position for loading/unloading from the canister-positioning equipment.

- Detect the glass level in the canister as it is being filled to assure proper level of filling and no overflow. Also weigh the canister.

- Decontaminate the canister exterior after covering the opening of the canister.

- Remove, to regulated limits, radioactive particulate matter, toxic gases, and vapors from the process gases prior to their release to the environment.

- Provide process solution re-use and recycle features to minimize derivative waste disposal demands.

- Provide a capability to collect representative process samples for laboratory analysis. Provide remote sampling and sample transfer capabilities.

- Provide monitoring and control systems during normal and emergency operating conditions for all potentially radioactive releases to the environment. Maintain the releases below current state and federal regulatory limits to provide protection to the general public and site personnel.

- Provide design features to maintain internal and external radiation exposures to operating and maintenance personnel as low as reasonably achievable (ALARA).

- Maximize the use of low-maintenance process equipment in radioactive areas.

\subsection{Process Description ${ }^{(5)}$}

The vitrification process is depicted in Figure 2.1. 
Prior to its introduction into the Vitrification Facility, the HLW was pretreated. A Supernatant Treatment System (STS) separated nonradioactive sodium ions from the high-level waste by passing it through ionexchange columns containing zeolite which retained the radioactive ${ }^{137} \mathrm{Cs}$, while allowing the sodium to pass. This was done to minimize the amount of glass that would need to be produced by the vitrification process. Sulfate was then washed from the sludge by adding water and agitating, followed by settling, decanting, and treatment of the wash solution by the STS. This was done to improve the quality of the glass that would be produced. The zeolite from the STS, with the ${ }^{137} \mathrm{Cs}$, was returned to the $\mathrm{HLW}$ and the aqueous, low-level byproduct solution was further treated and ultimately solidified into concrete in steel drums and stored in the Drum Cell.

The zeolite and the THOREX process wastes are combined with the washed sludge and mixed. The resulting slurry is transferred in batches to a Concentrator Feed Make-up Tank (CFMT) where the slurry is concentrated and sampled. The samples are analyzed to determine the amounts of glass-forming and oxidation-control ingredients to be added. The adjusted slurry is then transferred to the Melter Feed Hold Tank (MFHT); a surge tank between the batch-operated CFMT and the continuously fed melter. From the MFHT, the slurry is transferred into the Slurry-fed Ceramic Melter $(\mathrm{SFCM})$, operated at $1,150^{\circ} \mathrm{C}\left(2,100^{\circ} \mathrm{F}\right)$ to produce borosilicate glass. The molten glass is air-lifted over a pour spout to a canister on a turntable. The canisters of glass are capped, decontaminated, and transferred for interim storage in a cell of the former reprocessing plant where they will remain until a federal repository becomes available. Approximately 300 canisters of high-level waste will be produced.

The off-gases from the melter, mostly water vapor and oxides of nitrogen $\left(\mathrm{NO}_{\mathrm{x}}\right)$, are quenched and scrubbed in a submerged bed scrubber (SBS), processed through a high-efficiency mist eliminator (HEME), and filtered before leaving the shielded Vitrification Cell. Before release, the off-gases are further filtered through highefficiency particulate air (HEPA) filters and the $\mathrm{NO}_{\mathrm{x}}$ is treated by selective catalytic destruction. 


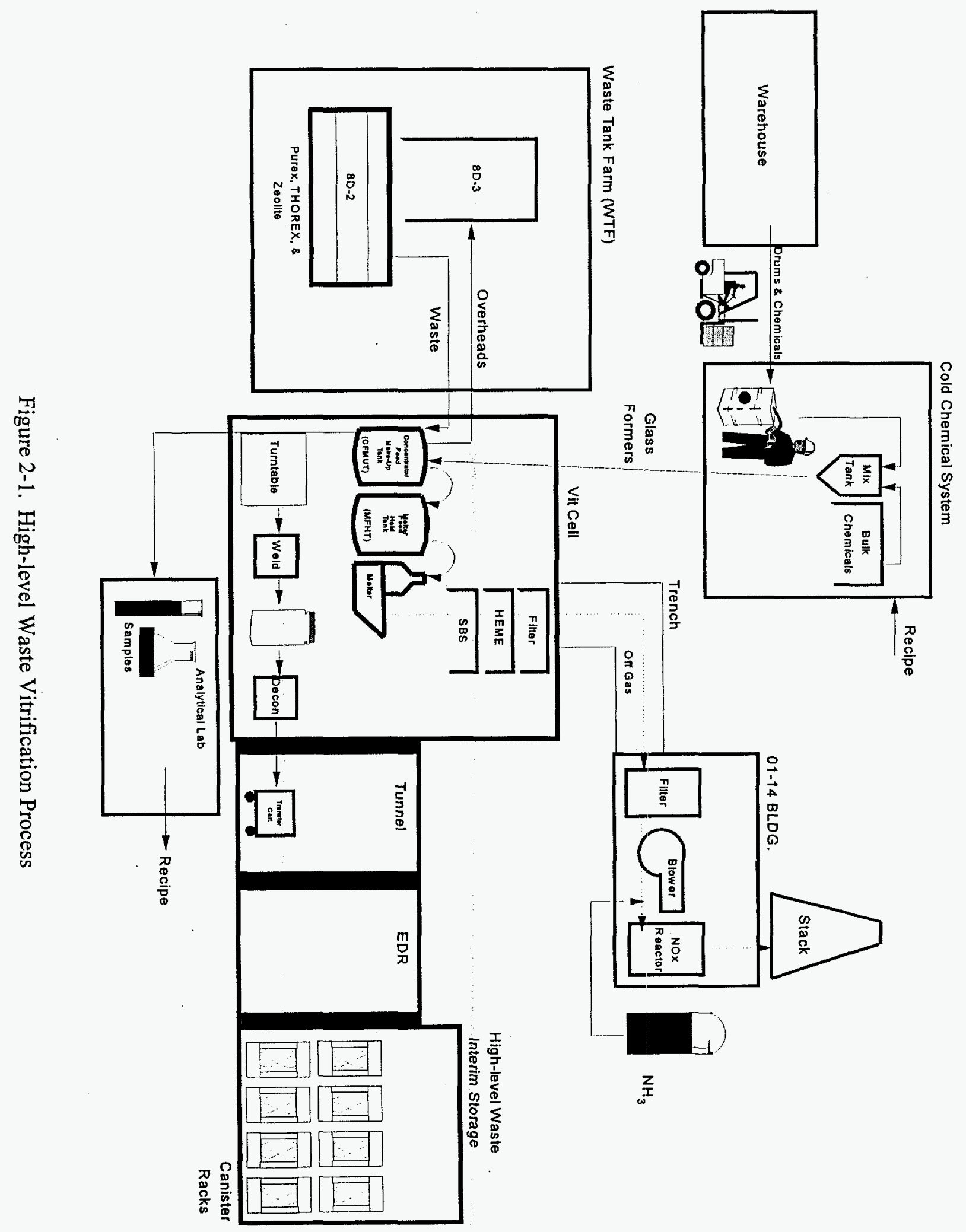




\subsection{Facility Lay-out}

The overall Facility lay-out is presented in Figure 2.2.

The Vitrification Facility is located adjacent to the HLW Tank Farm, where the waste was located at the initiation of the Project, and between the HLW Tank Farm and the Main Building of the former reprocessing plant, the location of the interim storage cell for the vitrified waste.

A cold chemical facility, where the glass-forming chemicals are received and prepared for delivery to the vitrification process, is located adjacent to the Vitrification Facility. It was designed as an independent facility to assure that the glass formers would not become radioactively contaminated prior to delivery to the process.

The melter feed preparation equipment (CFMT, MFHT, sample station, and vessel ventilation) are located within a shielded Vitrification Cell inside the Vitrification Facility, together with the melter and canister processing equipment (turntable, weld station, and decontamination station). A transfer tunnel was built between the Vitrification Facility and the Main Building of the former reprocessing plant to allow shielded transfer of the canisters of HLW, with the assistance of a transfer cart, to the HLW Interim Storage (HLWIS) location. The HLWIS location is the decommissioned and decontaminated Chemical Process Cell of the former reprocessing plant, which has been equipped with special canister storage racks. The initial off-gas treatment devices (SBS, HEME, and prefilters) are located inside the Vitrification Cell in order to collect the overwhelming majority of the radioactivity behind that Cell's shield walls, thereby keeping radiation exposures to the operators ALARA. The partially treated off-gases are transferred from the Vitrification Facility in a duct located underground in a trench to the final off-gas system located in the 01-14 Building. In the 01-14 Building, the off-gases are prepared for release by HEPA filtration and selective catalytic destruction of the $\mathrm{NO}_{\mathrm{x}}$ gases. The off-gas blowers are located downstream from the final HEPA filters so that they can be maintained by hands-on methods.

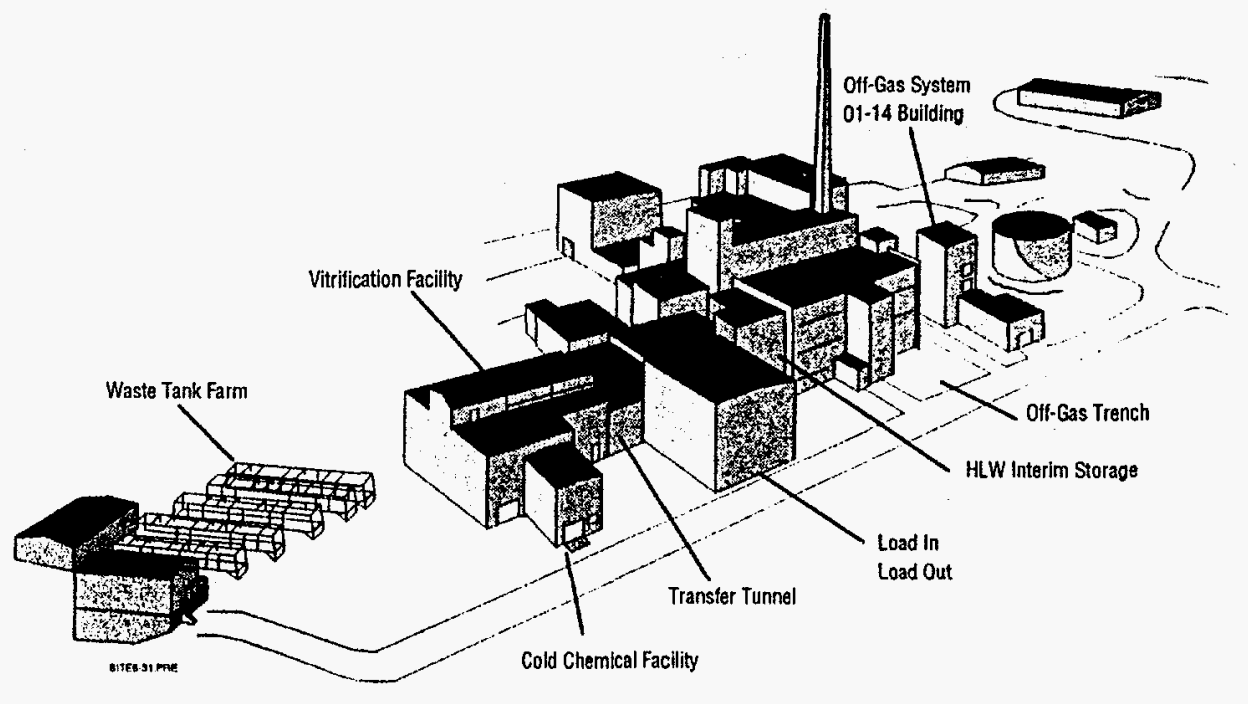

Figure 2.2 High-level Waste Solidification Facilities 


\subsection{EQUIPMENT DESCRIPTION}

\subsection{Sludge Mobilization and High-level Waste Transfer System}

\subsubsection{Functional Requirements ${ }^{(6)}$}

The functions of the sludge mobilization and high-level waste transfer system are to resuspend the settled PUREX process waste sludge at the Tank Farm, remove wastes from the tanks, and deliver them to the Vitrification Facility.

\subsubsection{Process Descriptions}

To reduce the salt content of the neutralized PUREX process wastes, especially sodium salts and sulfate salts which would have adverse impacts on the vitrification process, the sludge in Tank 8D-2 was mobilized and washed. This was accomplished by adding water to the sludge, mixing the water and sludge using the mobilization pumps, then decanting the wash water to a separate system for processing.

This system was subsequently used to transfer the acidic THOREX process waste solution from stainless steel Tank 8D-4 in order to combine the THOREX process waste with the basic PUREX process waste sludge in carbon steel Tank 8D-2 while adding sodium hydroxide to neutralize the acidic waste, thereby protecting the carbon steel tank from corrosion. The mixture was then washed to remove the sodium added during the THOREX neutralization process.

The system was next used to transfer the ${ }^{137}$ Cs-loaded zeolite as a slurry to Tank $8 \mathrm{D}-2$ to be blended with the wastes already there. A grinder in the transfer line reduced the zeolite particle size from about $850 \mu \mathrm{m}(2.8 \mathrm{x}$ $\left.10^{-3} \mathrm{ft}\right)$ to about $50 \mu \mathrm{m}\left(164 \times 10^{-6} \mathrm{ft}\right)$.

The blended wastes are then transferred, in batches, to the CFMT located inside the Vitrification Cell of the Vitrification Facility.

\subsubsection{Hardware Description}

The sludge and zeolite mobilization pumps are shown in Figure 3.1. These pumps provide the mixing that results in a homogeneous feed transfer to the Vitrification Facility. They are deep-well, long-shafted, lowpressure, high-flow, centrifugal pumps that discharge beneath the complex gridwork on the bottoms of the tanks. Five such pumps are installed in High-level Waste Tank 8D-2.

Each sludge and zeolite mobilization pump is operated by a $110 \mathrm{~kW}(150 \mathrm{hp})$ motor with an adjustable frequency drive that can run between $900 \mathrm{rev} . / \mathrm{min}$. and 2,100 rev./min. Each mobilization pump is supported

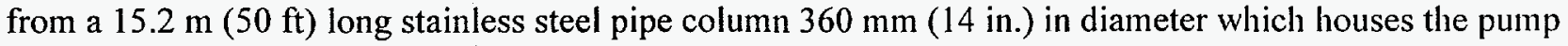
drive shaft. Each shaft is filled with water to lubricate the shaft bearings and provide radiation shielding. The column of water puts static pressure on the shaft's lower seal to inhibit the tank contents from entering the pump columns. Each pump has two $38 \mathrm{~mm}$ ( $1.5 \mathrm{in}$.) diameter tangential discharge nozzles approximately 250 $\mathrm{mm}\left(10 \mathrm{in}\right.$.) from the tank floor. The pumps operate at a flow rate of $2.27 \mathrm{~m}^{3} / \mathrm{min}$. $(600 \mathrm{gpm})$ out of each nozzle. The nozzles are continuously rotated $2 \mathrm{~B}$ radians (360 degrees) at a rotational speed of $0.5 \mathrm{rev} . / \mathrm{min}$. 
The sludge and zeolite mobilization pump support structure consists of steel trusses resting on concrete piers. None of the loads are imparted to the tops of the tanks or to the concrete vaults housing the tanks.

The transfer pumps are centrifugal, multistage, turbine-type pumps. They consist of a series of pump bowls that house the impeller and a vertical column through which the pump shaft rises to the motor. They are sized to make transfers at rates from $0.23 \mathrm{~m}^{3} / \mathrm{min}$. to $0.27 \mathrm{~m}^{3} / \mathrm{min}$. (60-70 gpm). These flow rates provide fluid velocities from $1.8 \mathrm{~m} / \mathrm{s}$ to $2.1 \mathrm{~m} / \mathrm{s}(6 \mathrm{ft} / \mathrm{sec}$. to $7 \mathrm{ft} / \mathrm{sec}$.) to prevent settling of solids in the line during transfer. 


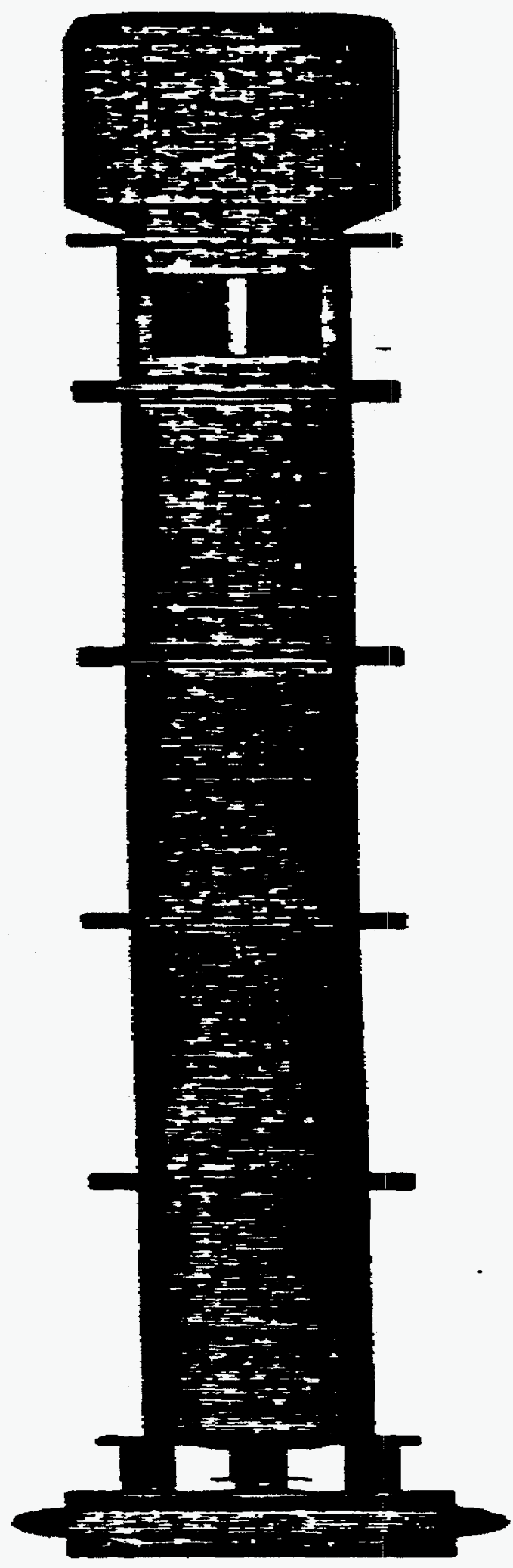

Figure 3.1. Sludge Mobilization Pump 


\subsection{Concentrator Feed Make-up Tank}

\subsubsection{Functional Requirements ${ }^{(7)}$}

The Concentrator Feed Make-up Tank (CFMT) receives all ingredients required to make the borosilicate glass, including high-level radioactive waste from the Tank Farm, glass-forming chemicals, and nitric acid to acidify the waste hydroxides. The CFMT also receives solutions that are recycled from the melter off-gas treatment system and the zeolite used to pretreat the high-level waste. The CFMT evaporates water from the slurry to achieve the desired waste concentration.

\subsubsection{Process Description ${ }^{(7)}$}

Recycle water from the vitrification process is transferred from the SBS to the CFMT, then the CFMT is filled to near capacity, at a rate of $250 \mathrm{l} / \mathrm{min}$. (65 gpm), with waste from the Tank Farm. Nitric acid is added to acidify the waste sufficiently to provide up to a 2 molar nitric acid melter feed, after evaporation.

The contents of the CFMT are sampled and the samples are analyzed while the excess water is evaporated. Evaporation is accomplished by heat transfer from steam applied through a half-pipe jacket fitted around the vessel shell.

The CFMT was designed to evaporate excess water from the slurry contents at $1.1 \mathrm{~m}^{3} / \mathrm{h}(300 \mathrm{gal} . / \mathrm{hr})$, while maintaining a minimum condensate decontamination factor of 1,000 for zeolite particles $7 \mu \mathrm{m}$ to $50 \mu \mathrm{m}(23 \mathrm{x}$ $10^{-6} \mathrm{ft}$ to $160 \times 10^{-6} \mathrm{ft}$ ) in the feed. ${ }^{(8)}$

After the contents of the CFMT are boiled down and the analytical results are known, glass-forming chemicals are added to establish the desired melter feed recipe. The resulting slurry has an oxide concentration of $300 \mathrm{~g} / 1$ to $550 \mathrm{~g} / \mathrm{l}\left(2.5 \mathrm{lb}_{\mathrm{m}} /\right.$ gal. to $\left.4.6 \mathrm{lb}_{\mathrm{m}} / \mathrm{gal}.\right)$.

The contents are again sampled and analyzed to verify that the concentrations of the constituents in the slurry are within an acceptable ranges. The slurry is then cooled by passing cooling water through the half-pipe jacket. The CFMT was designed to cool the slurry contents from $100^{\circ} \mathrm{C}\left(212^{\circ} \mathrm{F}\right)$ to $40^{\circ} \mathrm{C}\left(104^{\circ} \mathrm{F}\right)$ in less than 8 hours.

Throughout operations in the CFMT the slurry is maintained in a homogeneous state by operation of an agitator. The agitator was designed to re-suspend solids in the event the agitator has been shut off for a period of time.

The prepared slurry is transferred by steam jet to the MFHT.

The internals of the CFMT are maintained under a slight vacuum, relative to the Vitrification Cell ambient, by the vessel ventilation system.

\subsubsection{Hardware Description}

The CFMT is depicted in Figure 3.2. 
The CFMT has an inside diameter of $3,000 \mathrm{~mm}(10 \mathrm{ft})$. Its height is $4,000 \mathrm{~mm}(13 \mathrm{ft})$ from the bottom of the 2:1 elliptical head to the agitator flange. An elliptical bottom head was selected to minimize the heel, improve solids suspension, and reduce stress corrosion cracking by minimizing stress levels. The top head is a standard flanged and dished head to minimize vessel height without using internal gussets.
Max. operating volume
$22.6 \mathrm{~m}^{3}$
(5,970 gal.)
Min. operating volume
$3.89 \mathrm{~m}^{3}$
(1,030 gal.)
Design pressure, shell
$-30 \mathrm{kPa}$
$(-120$ in. WC)
Design pressure, jacket
$1.0 \mathrm{MPa}$
(150 psig)
Design temperature
$185^{\circ} \mathrm{C}$
$\left(365^{\circ} \mathrm{F}\right)$

All nonreplaceable vessel components that are wetted by the waste slurry are made of Hastelloy ${ }^{\mathrm{TM}} \mathrm{C}-22$. This material was selected based on corrosion tests using boiling waste slurry. Components that are not in contact with boiling process fluids are fabricated from Type 304L stainless steel. Process connections are made either to PUREX connectors or to remotely connectable flanges, which use locating studs and free nuts. Flange gaskets are Viton $^{\mathrm{TM}}$ attached to a Type $304 \mathrm{~L}$ stainless steel carrier. Replaceable components such as jumpers are also made from Type 304L stainless steel.

The CFMT exterior is partially covered by two half-pipe coil heating/cooling jackets: one on the tank wall and one on the bottom head. An external jacket design was chosen to eliminate the solids accumulation trap that would exist with internal coils. The half-pipe jacket design was chosen because it resulted in the lightest total weight and because of better heat transfer control to the tank wall. The coils are dimensionally $89 \mathrm{~mm}$ (3-1/2 in.), schedule 10 pipe, covered with $25 \mathrm{~mm}$ ( $1 \mathrm{in}$.) of fiberglass blanket and 14-gauge, Type 304L stainless steel sheet. The coils are extended up to the vessel top by $76 \mathrm{~mm}$ ( $3 \mathrm{in}$.), schedule 40 , Type $304 \mathrm{~L}$ stainless steel pipe, to facilitate remote connecting of service jumpers. The CFMT is supported on a skirt from the bottom head.

The agitation system consists of two $965 \mathrm{~mm}(3 \mathrm{ft}, 2 \mathrm{in}$.) diameter, axial-flow, high-efficiency impellers (three blades each), and four, equally spaced, standard, $300 \mathrm{~mm}$ (12 in.) wide mixing baffles, with a $25 \mathrm{~mm}$ ( 1 in.) gap between the baffles and the tank wall. The agitator impeller blade material is Stellited Hastelloy ${ }^{\mathrm{TM}}$ for erosion resistance. The agitator is driven at $188 \mathrm{rpm}$ by a $30 \mathrm{~kW}(40 \mathrm{hp})$, single-speed, 1,800 rpm, 460-Volt, 3-phase motor with a gearbox.

The jet used to transfer slurry from the CFMT to the MFHT is driven with $690 \mathrm{kPa}(100 \mathrm{psig})$ steam and has a nominal capacity of $0.28 \mathrm{~m}^{3} / \mathrm{min}$. (75 gpm). 


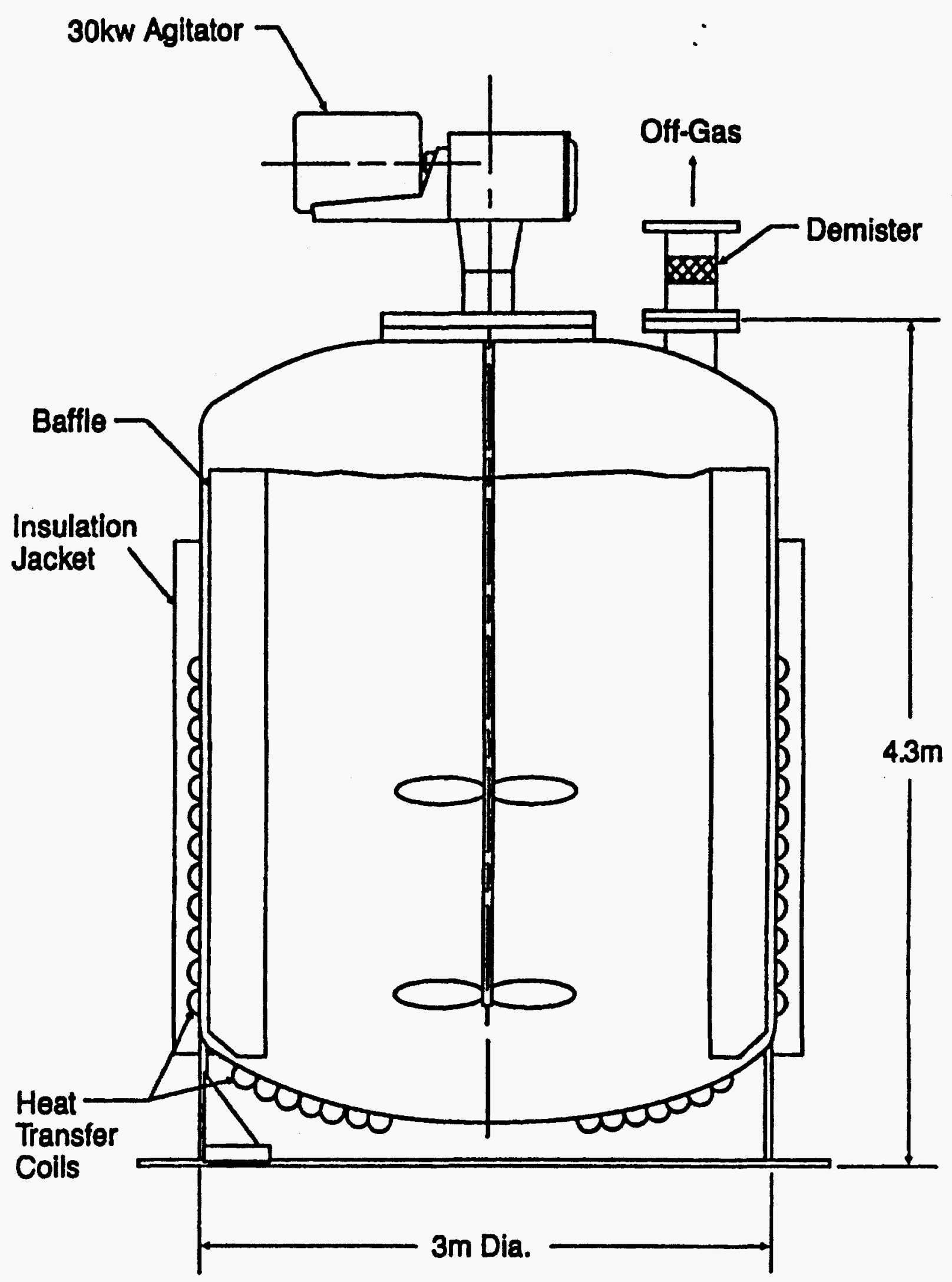

Figure 3.2. Concentrator Feed Make-up Tank ${ }^{(9)}$ 


\subsection{Slurry Sample System}

\subsubsection{Functional Requirements ${ }^{(10)}$}

The function of the slurry sampling system is to extract samples of high level waste and feed slurries for analysis. Results of the analyses are used to determine the proper chemical additions for feed make-up operations.

\subsubsection{Process Description}

The tank to be sampled is agitated to assure that samples will properly represent the contents of the tank. An air displacement slurry pump is used to circulate a stream of slurry at $150 \mathrm{l} / \mathrm{h}(40 \mathrm{gph})$ from the tank to a sample station then back to the tank. Part of the stream is collected in a small bottle as it flows through the sample station. The bottle of slurry is submitted to an analytical laboratory for analysis.

\subsubsection{Hardware Description}

The slurry sample station, shown in Figure 3.3, is approximately $2,000 \mathrm{~mm}(6 \mathrm{ft})$ long and $1,000 \mathrm{~mm}(3 \mathrm{ft})$ deep, with supports on one side for mounting it to the cell wall. The station consists of two sampler modules, one for the CFMT and one for the MFHT. The sampler modules consist of a slurry sampler, a flow meter, and flow control valves. Wetted parts are manufactured from Type 304L stainless steel for corrosion resistance.

The sample vials are manufactured from glass, with plastic caps having butyl septums to accept the needles of the sample modules. Each vial has a volume of about $13 \mathrm{ml}(15 / 32$ fluid oz).

The sample station is located at a Vitrification Cell window and is operated using manipulators. 
SAMPLE MODULE

SAMPLE MODOLE

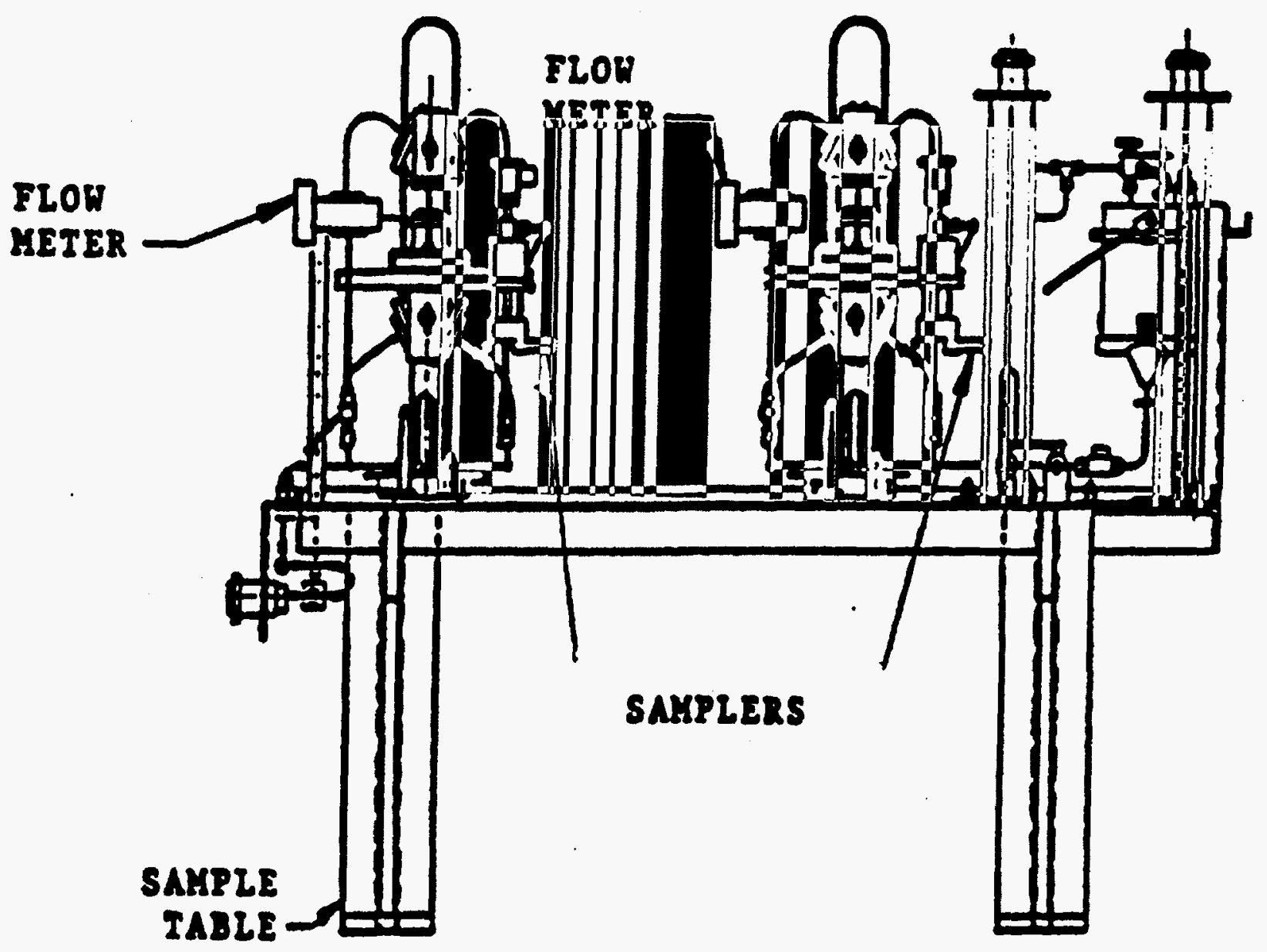

Figure 3.3. Slurry Sample Station 


\subsection{Melter Feed Hold Tank}

\subsubsection{Functional Requirements ${ }^{(8)}$}

The functional requirements for the MFHT are as follows:

- Sufficient operating volume to permit uninterrupted melter feeding during preparation of the subsequent feed batch in the CFMT

- Interior design that prevents deposition of solids in excess of quantities allowed by feed composition acceptance limits

- Agitation to maintain slurry homogeneity within acceptance limits for feed qualification

- Reliable level and density measurements of the slurry contents

- Maintenance of the slurry temperature at or below $40{ }^{\circ} \mathrm{C}\left(104^{\circ} \mathrm{F}\right)$ while the agitator is operating.

The agitator was designed to re-suspend solids in the event the agitator has been shut off for a period of time.

\subsubsection{Process Descriptions}

Melter feed slurry is accepted in batches from the CFMT for delivery to the melter.

The slurry in the MFHT is kept in a homogeneous state by operation of an agitator. The slurry is fed continuously to the melter by an air displacement slurry (ADS) pump. Slurry feed can continue as long as the slurry level in the tank remains above the minimum acceptable level for adequate mixing.

The internals of the MFHT are maintained under a slight vacuum, relative to the Vitrification Cell ambient, by the vessel ventilation system.

\subsubsection{Hardware Descriptions}

The MFHT, shown in Figure 3.4, is a cylindrical vessel, having an outside diameter of 3,050 mm (10 ft). Its height is $3,050 \mathrm{~mm}(10 \mathrm{ft})$ from the bottom of the flanged, flat, bottom head to the top of the flanged, flat, top head. The flat bottom was chosen to facilitate access to the low point of the tank from any nozzle. The flat top was chosen to minimize vessel height. Internal stiffeners are installed in the top head.
Max. operating volume
$18.9 \mathrm{~m}^{3}$
(5,000 gal.)
Min. operating volume
$4.00 \mathrm{~m}^{3}$
(1,000 gal.)
Design pressure, shell
$7.5 \mathrm{kPa}$
(30 in. WC)
Design vacuum, shell
$7.5 \mathrm{kPa}$
(30 in. WC) 
Design pressure, jacket

Design temperature
$140 \mathrm{kPa}$

$120^{\circ} \mathrm{C}$
(20 psig)

$(248 \mathrm{n} F)$

All vessel components are made of Type 304L stainless steel.

The exterior of the MFHT is partially covered by a cooling jacket. This jacket has internal baffles that cause the water flow to spiral within a rectangular channel $275 \mathrm{~mm}(10-13 / 16 \mathrm{in}$.) high and $44 \mathrm{~mm}(1-3 / 4 \mathrm{in}$.) wide.

The agitation system consists of two $914 \mathrm{~mm}(3 \mathrm{ft}$ ) diameter, axial-flow, high-efficiency impellers (three blades each), and four equally spaced standard baffles, with a $110 \mathrm{~mm}$ (4.5 in.) gap between the baffles and the tank wall. The agitator impeller blade material is Stellited Hastelloy ${ }^{\mathrm{TM}}$ for erosion resistance. The agitator is driven at $155 \mathrm{rpm}$ by an $11 \mathrm{~kW}(15 \mathrm{hp})$, single-speed, 1,800 rpm, 460-Volt, 3-phase motor with a gearbox. 


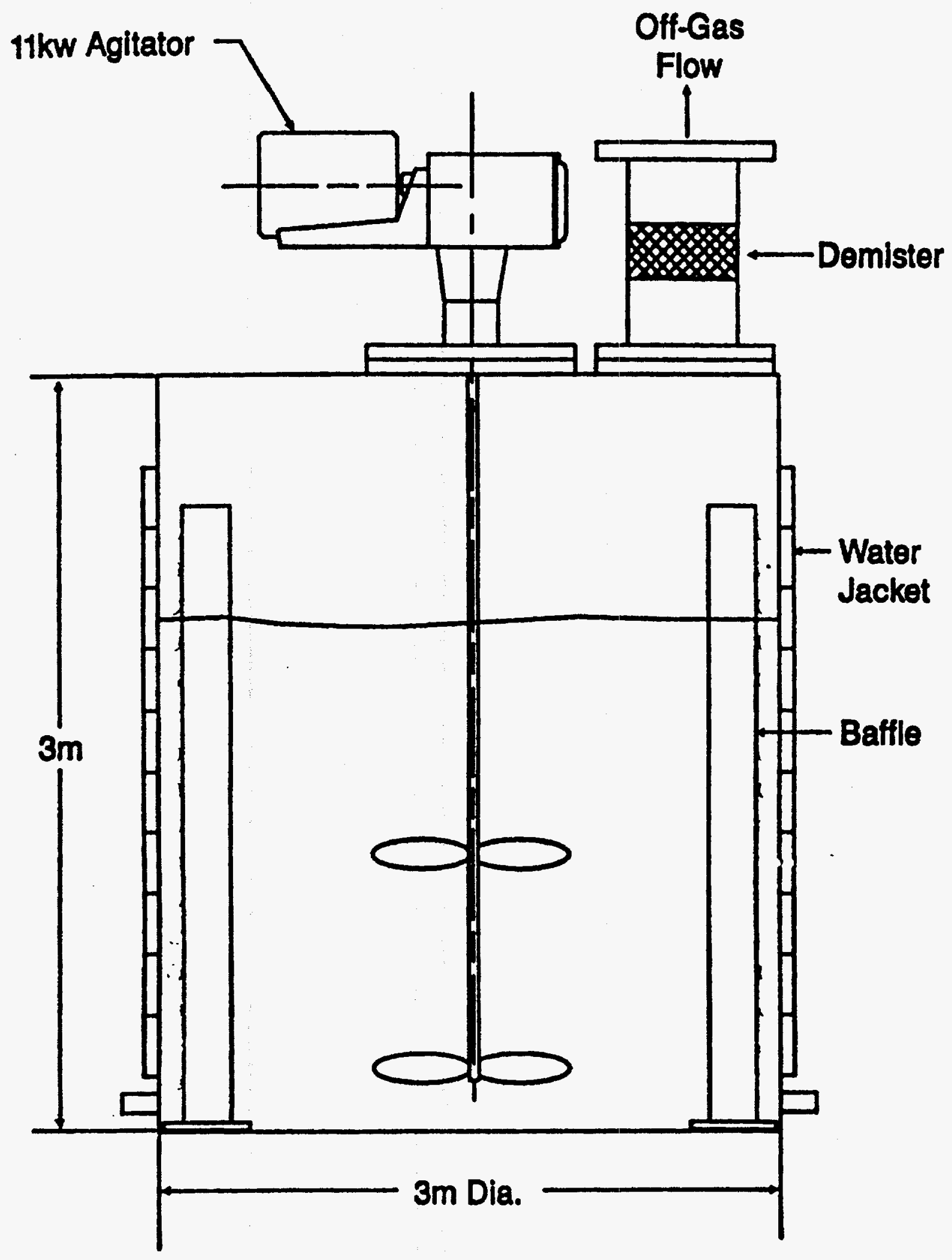

Figure 3.4. Melter Feed Hold Tank ${ }^{(9)}$ 


\subsection{Melter Feed Pump}

\subsubsection{Functional Requirements ${ }^{(11)}$}

The feed delivery system is required to deliver melter feed from the MFHT to the SFCM at a controlled rate between $20 \mathrm{l} / \mathrm{h}(5 \mathrm{gph})$ and $150 \mathrm{l} / \mathrm{h}(40 \mathrm{gph})$.

\subsubsection{Process Description ${ }^{(8)}$}

The melter feed pump is an ADS pump. The slurry inlet is located near the bottom of the MFHT. Valve actuation is accomplished by a programmed series of steps, as depicted in Figure 3.5. Following feed slurry transfer, the bottom of the pump is opened to permit the flow of slurry into the chamber. After the slurry has filled the chamber, but before solids significantly settle, the poppet drops to seal the lower seat and air is added to the chamber, pushing slurry out of the pump to the melter.

\subsubsection{Hardware Description}

The ADS pump contains a 1.41 ( 0.37 gal.) chamber. The slurry entrance is shrouded by a $\# 4$ mesh screen. The line to the melter is a $9.5 \mathrm{~mm}(3 / 8 \mathrm{in}$.), schedule 40 , pipe.

The ADS pump is made of Type 304L stainless steel, except for the moving parts such as the push rod, rocker arm, and poppet, which are made of Carpenter Custom $450^{\mathrm{TM}}$ stainless steel for abrasion resistance. 


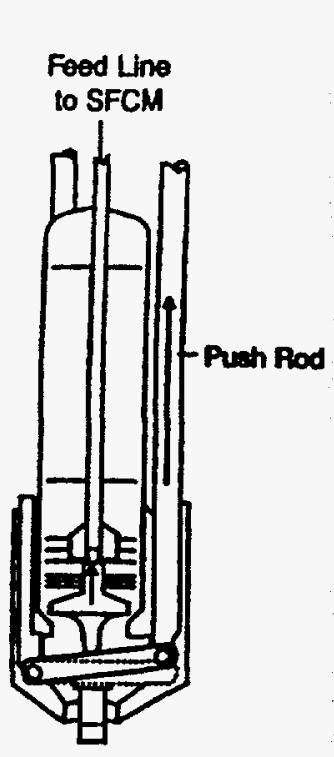

Cycle 1

Vent

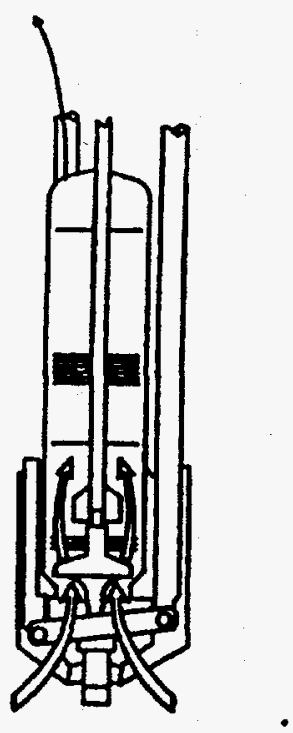

Cycle 2

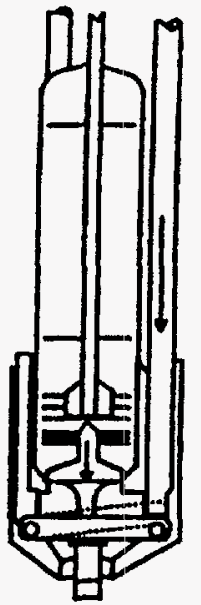

Cycle 3

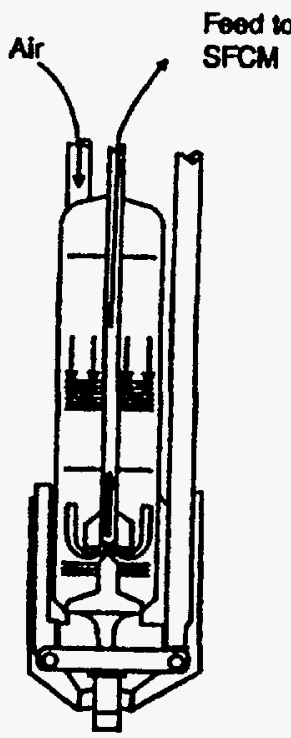

Cycle 4

Punh Rod mover Poppet (Check Valve) to the Opponition, thus openting the Chniber to Mry c clonting the raed Itno to stax.

8luryy in Mry enter: Rub Rod nover Poppet and Fil1. the Chniber. to the Down ponition. AI is ronted back into the Mrar. thueloring Chnber

to Mrix \& opening

Fend ritne to teh sFor.
Mix enters the Chamber and forces the slury up the Iread Inse to the srax.

Figure 3.5. Air Displacement Slurry Pump ${ }^{(2)}$ 


\subsection{Slurry-fed Ceramic Melter}

\subsubsection{Functional Requirements ${ }^{(12)}$}

The Slurry-fed Ceramic Melter (SFCM) converts slurried, high-level waste to an acceptable borosilicate glass.

\subsubsection{Process Description ${ }^{(8)}$}

Initial heat-up of the melt cavity is accomplished by radiant heat transfer from electric heaters positioned above the glass pool. When the temperature of the glass reaches $800^{\circ} \mathrm{C}\left(1,470^{\circ} \mathrm{F}\right)$ the electrodes are energized to heat the glass by Joule heating to the operating temperature of $1,050^{\circ} \mathrm{C}$ to $1,150^{\circ} \mathrm{C}\left(1,900^{\circ} \mathrm{F}\right.$ to $\left.2,100^{\circ} \mathrm{F}\right)$.

The electrode temperature is limited to $1,150^{\circ} \mathrm{C}\left(2,100^{\circ} \mathrm{F}\right)$ by an air-operated cooling system.

Feed slurry is delivered continuously to the melter at a rate of 60 to $80 \mathrm{l} / \mathrm{h}$ (16 to $21 \mathrm{gal} / \mathrm{hr}$ ). In the melter, water evaporates from the slurry and the remaining solids calcify. Calcined wastes and glass formers melt into the glass pool where they mix by natural convection. The glass product is in the melter for an average residence time of 40 to 70 hours, depending on the slurry feed rate.

The status of the melting process is determined by monitoring the temperature of the melt and of the freeboard space above the melt, as well as by qualitative visual assessment using a melter plenum viewing system.

Molten glass is transferred from the melter cavity by airlift to a spout. Air is bubbled into the overflow passage, displacing glass and raising the level of the melt in the passage, causing it to intermittently flow from the melter. From the spout, the melt pours into a canister positioned below the spout. Radiant heaters in the discharge channel keep the melt hot to prevent it from hardening before entering the canister. Flow into the canister is proven by visual observation using the glass pour viewing system.

The glass production rate is about $30 \mathrm{~kg} / \mathrm{h}(66 \mathrm{lb} / \mathrm{hr})$. The total time to fill each canister is about 63 hours.

The off-gas and vessel ventilation system is operated to maintain the melter plenum at $-1.2 \mathrm{kPa}(-5.0 \mathrm{in}$. WC) relative to cell pressure.

A film cooler in the off-gas exit from the melter introduces air to provide initial cooling without going below the off-gas dew point, and to provide a boundary layer of air near the walls to minimize material deposition.

A film cooler cleaner prevents blockage in the melter off-gas exit nozzle by periodically dislodging accumulated deposits with a wire brush.

\subsubsection{Hardware Description}

The overall dimensions of the melter, shown schematically in Figure 3.6-1, are approximately $3.05 \mathrm{~m}$ wide by $3.05 \mathrm{~m}$ high by $3.05 \mathrm{~m}$ in depth $(10 \mathrm{ft} \times 10 \mathrm{ft} \times 10 \mathrm{ft})$. The melter cavity is lined by a composite of various refractory materials in contact with the molten glass, encased inside a water-cooled metal box. The discharge section of the melter has two pour chambers and two pour spouts; a primary and a backup. The melter weighs approximately $48.1 \mathrm{Mg}$ (53 tons). 
The basic shape of the melter cavity is an inverted truncated rectangular pyramid. The walls of the vessel slope inward toward the bottom. The shape of the vessel was selected: (1) so that precipitated conductive materials would collect on the bottom electrode where it would cause minimal interference with electrode operation (2) to enhance the structural stability of the refractory lining and (3) to minimize the inventory in the melter in the event of a system failure. During normal operation, the melter cavity geometry will accommodate $0.86 \mathrm{~m}^{3}$ (227 gal.) of molten glass.

In addition to the main chamber melting cavity, the melter interior includes the overhead plenum and two pour spouts.

The Joule heating system uses three electrode plates in the melter in contact with the glass. Two of the three electrodes are located in the sides of the vessel. The third electrode serves as the floor of the vessel. The melter electrode extensions penetrate the concrete shield wall of the Vitrification Cell.

Radiant heating of the melt in the discharge chamber is provided by silicon carbide radiant heaters.

Water jackets on the sides and bottom provide cooling for the melter shell.

Air cooling is provided for the electrodes, the electrode shrouds for the wall penetrations, and the dam that separates the melter cavity from the discharge chambers. The cooling air is discharged to the Cell.

The assembled melter is designed for the following conditions:

Pressure (shell) $34 \mathrm{kPa}$

Vacuum (shell) $34 \mathrm{kPa}$

Pressure (jacket) $\quad 240 \mathrm{kPa}$
(5 psig)

(5 psig)

(35 psig)

The melter shell is fabricated from Type 304L stainless steel. Metal parts exposed to molten glass are of Inconel ${ }^{\mathrm{TM}} 690$, except for the air-lift pipes which are platinum. The melter is supported by a painted carbon steel structure that is bolted to the floor.

In the melter cavity where the refractory contacts molten glass, the refractory material is Monofrax $\mathrm{K}-3^{\mathrm{TM}}$. It was selected for its insulating properties and for its resistance to corrosion and erosion in a flowing-glass environment. The two riser blocks of the overflow chambers however, are of Monofrax- $\mathrm{E}^{\mathrm{TM}}$, which was selected not only for its corrosion and erosion resistance, but also for its higher thermal conductivity in order to maintain a high glass temperature in the riser between airlifts. Zirmul ${ }^{\mathrm{TM}}$ refractory was selected because of its higher insulating characteristic to back up the Monofrax ${ }^{\mathrm{TM}}$ refractories. Alfrax $66^{\mathrm{TM}}$ castable refractory backs up the Zirmul ${ }^{\mathrm{TM}}$ and Fiberfrax ${ }^{\mathrm{TM}}$ fiberboard back up the Alfrax ${ }^{\mathrm{TM}}$ because each in turn is a better insulator. Fiberfrax ${ }^{\mathrm{TM}}$ was also chosen for its compression resilience to accommodate the differential thermal growth between the refractory and the shell during thermal cycling.

For the plenum area of the melter cavity, where the refractory is not in contact with the molten glass, Monofrax- $\mathrm{H}^{\mathrm{TM}}$ refractory was selected for its superior resistance to glass vapor attack and thermal shock (The plenum routinely changes between $1,150^{\circ} \mathrm{C}\left[2,100^{\circ} \mathrm{F}\right]$ and $400^{\circ} \mathrm{C}\left[750^{\circ} \mathrm{F}\right]$ in short periods of time as feed slurry is either started or stopped, in contrast to the molten glass which is always maintained at about $1,150^{\circ} \mathrm{C}$ $\left[2,100^{\circ} \mathrm{F}\right]$.). The Monofrax- $\mathrm{H}^{\mathrm{TM}}$ is similarly backed-up with Zirmul $^{\mathrm{TM}}$, Alfrax $66^{\mathrm{TM}}$, and Fiberfrax ${ }^{\mathrm{TM}}$. 
The melter lid is lined with Alfrax $66^{\mathrm{TM}}$, backed by Alfrax BI- $57^{\mathrm{TM}}$ castable refractory and Fiberfrax $^{\mathrm{TM}}$, all attached to the lid by alumina anchors. Nozzles into the melter cavity have a replaceable Inconel ${ }^{\mathrm{TM}} 690$ liner to provide mechanical protection to the refractory during jumper installation and to provide corrosion protection to the melter lid. An air purge is provided for each Inconel ${ }^{\mathrm{TM}} 690$ liner by means of orifices in the liner flange, allowing cell air to be drawn into the annulus formed between the liner and the nozzle by means of the slight vacuum in the melter.

The two melter discharge chambers are separated from the melter cavity by the refractory wall that includes the riser blocks. Both are lined with Alfrax $66^{\mathrm{TM}}$ castable refractory, backed by Alfrax BI-57 ${ }^{\mathrm{TM}}$ castable and Fiberfrax $^{\mathrm{TM}}$. Inconel ${ }^{\mathrm{TM}}$ plates, called "dams," are cast into the Alfrax wall separating the melter cavity from the discharge chamber to prevent the possibility of glass seepage through the wall.

The thickness of each refractory brick layer was determined by the maximum interface temperature constraint.

Gaskets are Grafoil ${ }^{\mathrm{TM}}$ filled and jacketed with Type 316 stainless steel.

The film cooler, shown schematically in Figure 3.6-2, is located at the beginning of the off-gas discharge from the melter. It consists of a louvered insert that supplies a cool air flow along the inner surface of the pipe. It is fabricated from Inconel ${ }^{\mathrm{TM}} 690$.

The film cooler cleaner, shown schematically in Figure 3.6-3, is a pneumatically operated brush installed above the film cooler. Cleaner motion is accomplished by two pneumatic cylinders that cause the brush assembly to move downward when activated. As the shaft moves through the stationary roll nut, the shaft is forced to rotate causing the brush to take a helical path through the film cooler. The cleaner is withdrawn from the film cooler by adding air to the lower end of the two pneumatic cylinders causing the assembly to move upward.

The brush, and the shaft which carries the brush into the melter plenum, are both made of Inconel ${ }^{\mathrm{TM}} 690$. The roll nut rollers and the roll nut shaft are coated with tungsten disulfide as a lubricant. 


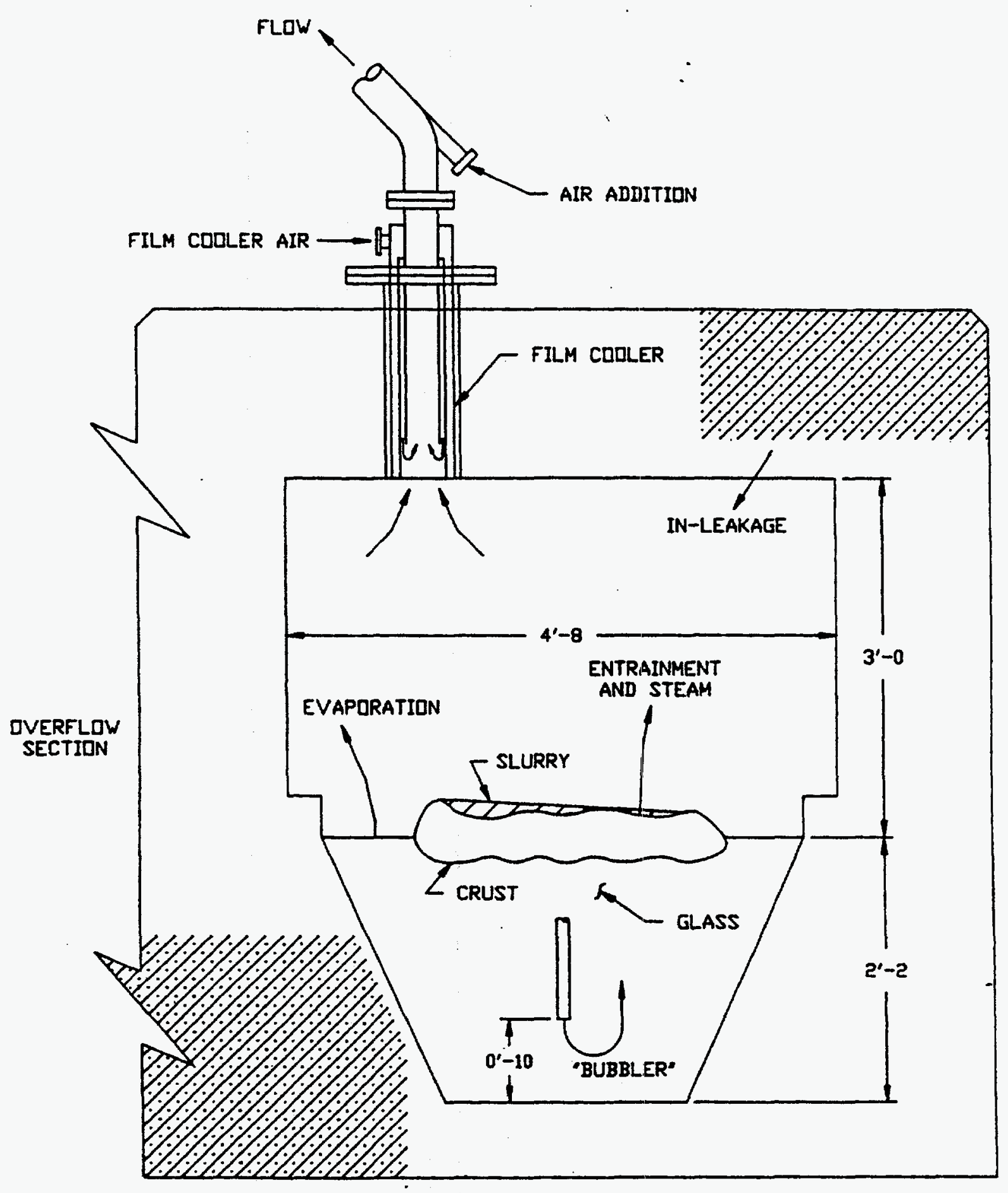

Figure 3.6-1. Slurry-fed Ceramic Melter 


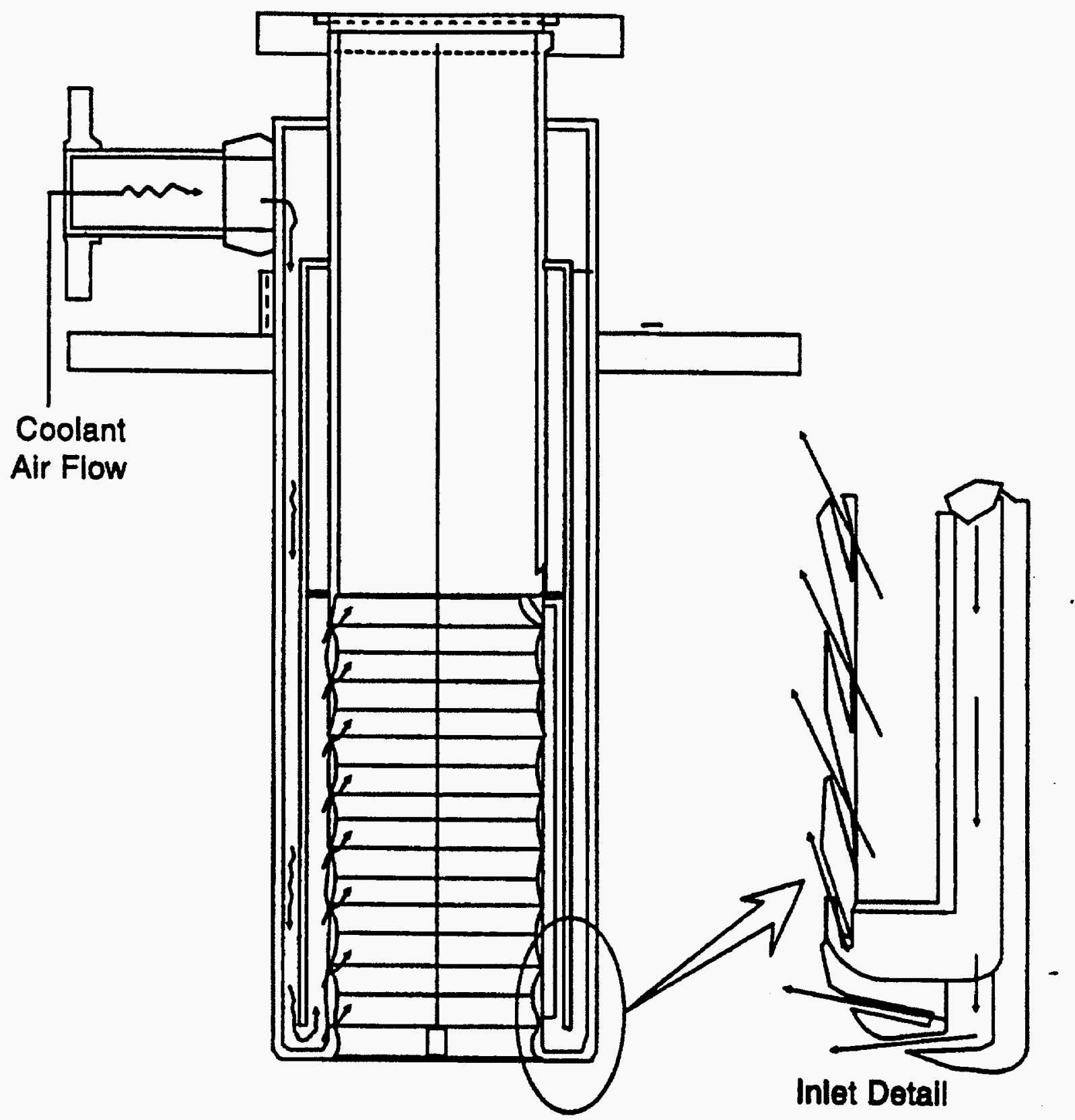

Figure 3.6-2. Film Cooler ${ }^{(9)}$ 


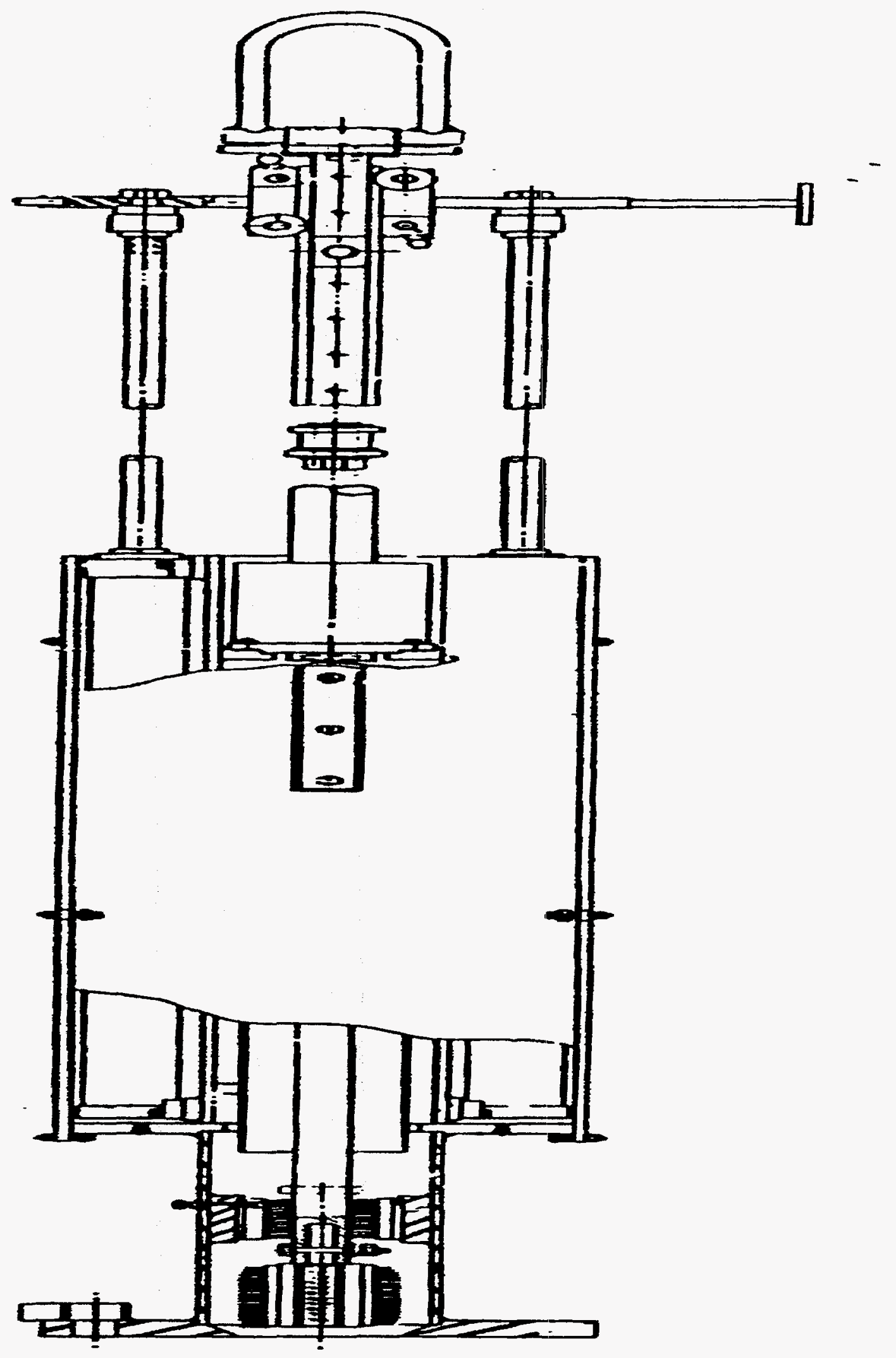

Figure 3.6-3. Film Cooler Cleaner 


\subsection{Canister}

\subsubsection{Functional Requirements}

The canister functions as mold within which the molten radioactive glass will solidify, and as a handling fixture for the radioactive glass "logs" within the canisters after the logs have become solid.

\subsubsection{Process Description}

Canisters are introduced into the Vitrification Facility at the Load-in Facility. They are transferred into the Vitrification Cell by the transfer cart, placed into the turntable where they receive molten glass from the melter, allowed to cool, moved to the weld station where they are sealed, moved to the decontamination station where the oxide layer that was formed when the hot glass was introduced is chemically removed, and finally moved by the transfer cart to the High-level Waste Interim Storage Facility (HLWISF) where they are placed into storage racks.

The canisters are filled to $87 \% \pm 5 \%$ full. This allows space for accumulation of the small amount of radon and helium gases expected from the decay of ${ }^{232} \mathrm{Th},{ }^{234} \mathrm{U},{ }^{235} \mathrm{U}$, and ${ }^{238} \mathrm{U}$. The space allowance provides for an increase in the pressure in the canister by only $10 \%$ after 100 years.

The geometric configuration of the canister provides for adequate cooling, by natural convection in dry storage, to prevent the radiation decay heat from heating the center line of the canister to the phase transition temperature of the glass, about $45^{\prime \prime} \mathrm{C}\left(113^{\circ} \mathrm{F}\right)$. One canister of vitrified waste is expected to generate 300 to 390 Watts $(1,000$ to $1,300 \mathrm{Btu} / \mathrm{hr})$ of energy. ${ }^{(13)}$

\subsubsection{Hardware Descriptions}

Each canister, depicted schematically in Figure 3.7, is a right cylinder, $610 \mathrm{~mm}(2 \mathrm{ft})$ in diameter, $3,000 \mathrm{~mm}$ (10 ft) tall, with a large-mouth top opening and a reverse-dished bottom head. A collar around the opening provides a means for handling the canister with a grapple suspended from a crane. The flanged face around the opening provides the surface for welding a lid to the top to seal the canister.

The canisters are made from Type $304 \mathrm{~L}$ stainless steel, with a minimum wall thickness of $3.4 \mathrm{~mm}(0.13 \mathrm{in}$.). 

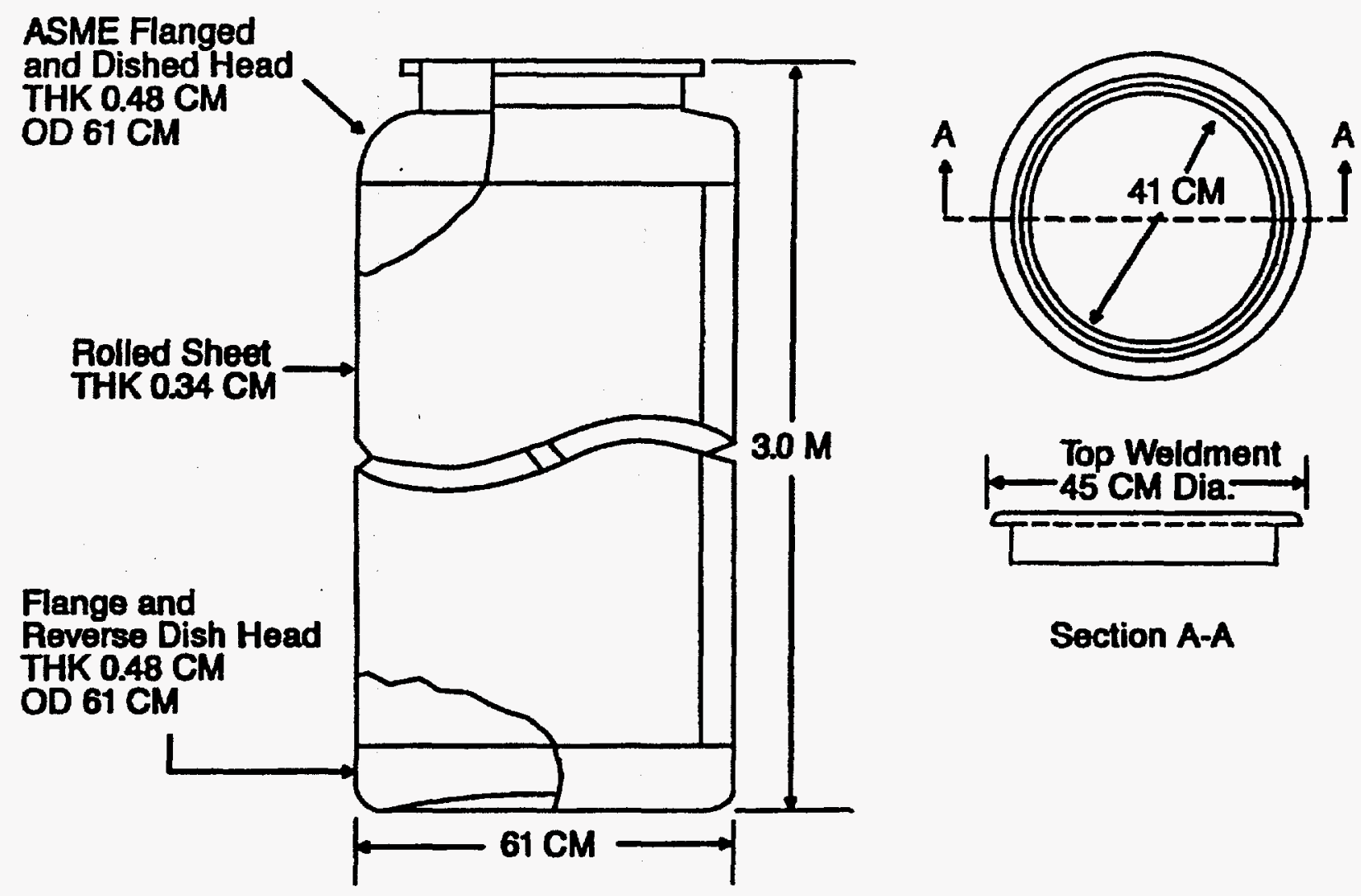

Section A-A

Figure 3.7. Canister 


\subsection{Turntable}

\subsubsection{Functional Requirements ${ }^{(14)}$}

The canister turntable positions empty canisters under one of two functional melter spouts, provides a sealed passageway for molten glass to flow from the melter to the canister, and weighs each canister as it is being filled.

\subsubsection{Process Description}

Canisters are placed into the turntable by a grapple attachment and overhead bridge crane.

Canisters are positioned under the melter overflow spout by the turntable. Empty canisters must be rotated into position for filling and also for weighing during filling. They are then rotated from underneath the melter pour spout for cooling and removal. During normal operations, while one canister is being filled, two canisters are cooling, and the fourth position is accessible for canister removal and replacement.

Each canister filled to $87 \% \pm 5 \%$ full, with about $2 \mathrm{Mg}\left(4,400 \mathrm{lb}_{\mathrm{m}}\right)$ of radioactive glass. Viewing the canister fill level is accomplished by an infrared level detection system (ILDS) that provides an indication of the glass level by recognizing the temperature gradient at the glass-air interface.

After filling, the turntable is rotated a quarter turn, which moves the just-filled canister away from the melter pour spout and places an empty canister under the spout. The filled canister is allowed to cool by natural convection while still in the turntable at two of the four turntable positions.

After cooling, each canister is transferred, by the grapple attachment and overhead bridge crane, to the canister weld station.

\subsubsection{Hardware Description}

The turntable, depicted in Figure 3.8, is designed to hold, weigh, and rotate, four loaded canisters with a maximum weight of $2.3 \mathrm{Mg}\left(5,000 \mathrm{lb}_{\mathrm{m}}\right)$ each, or a total of $9.1 \mathrm{Mg}(20,000 \mathrm{lb})$.

The canister turntable structure is made mostly of Type 304L stainless steel and consists of a stationary frame

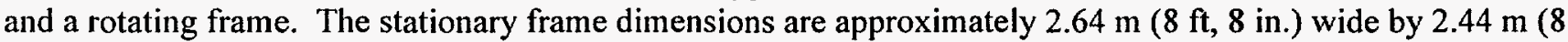

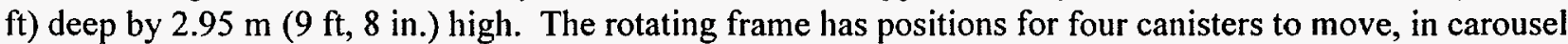
fashion, on a $1,690 \mathrm{~mm}(5 \mathrm{ft}, 6.5 \mathrm{in}$.) diameter circle. The carousel is driven by a $2.2 \mathrm{~kW}(3 \mathrm{hp})$ electric gear motor. The plate the canister pedestals ride upon is Type 430 stainless steel because it is a bearing surface.

The upper region of the turntable is sealed to the melter discharge section to minimize cell contamination from radionuclides evaporating from the glass pour stream. The seal is accomplished by allowing two bellows on the stationary structure to expand up until the bellows seal plates contact the discharge section seal plates.

The ILDS consists of an infrared-sensitive camera, operating in the $8 \mu \mathrm{m}$ to $12 \mu \mathrm{m}\left(30 \times 10^{-6}\right.$ to $\left.40 \times 10^{-6} \mathrm{ft}\right)$ spectrum. The camera is installed inside a shielding assembly to prolong life by delaying deleterious effects caused by exposure to ionizing radiation. 


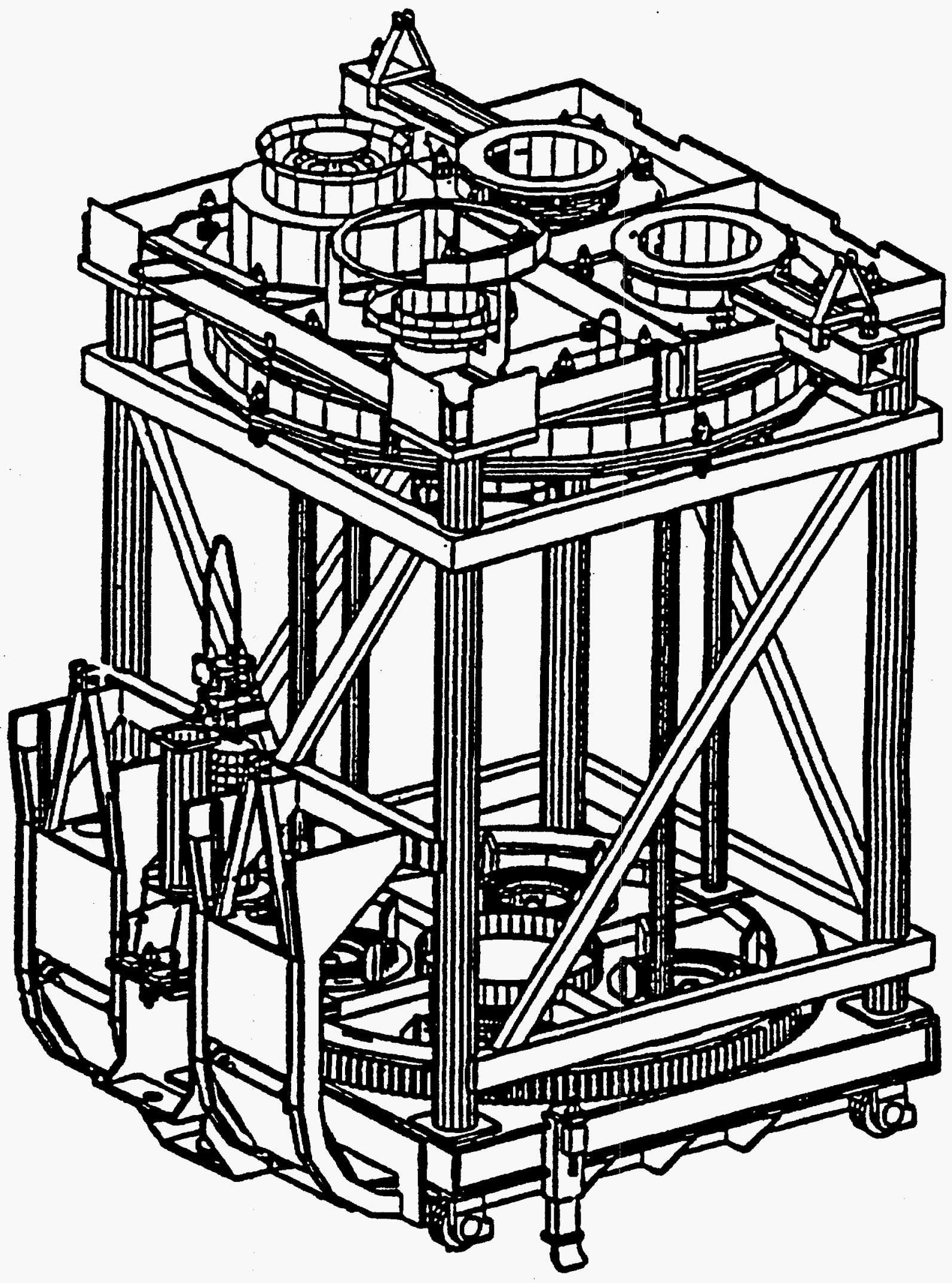

Figure 3.8. Turntable 


\subsection{Canister Grapple and Process Crane}

\subsubsection{Functional Requirements}

The functional requirement of the canister grapple/process crane combination is movement of the canisters regardless of whether they are empty, filled with glass but not capped, or filled with glass and capped.

\subsubsection{Process Description}

The canister grapple assembly is suspended from a process crane clevis and is actuated by raising and lowering a weighted portion of the assembly to drive a rotating ratchet assembly.

\subsubsection{Hardware Description ${ }^{(17)}$}

The canister grapple, shown in Figure 3.9, is a three-hook mechanized lifter, manufactured primarily from Type 304L stainless steel (Some Nitronic ${ }^{\mathrm{TM}} 60$ was used where resistance to galling was needed.). It is provided with one disengage position and two engage positions to avoid inadvertent actuation should a canister land on an obstacle. It is designed to assure full engagement and full disengagement so that a canister cannot be lifted while partially engaged. A status indicator is provided to show the operator the grapple position. A manipulator-operated override is provided to disengage the grapple should the actuation mechanism fail. 


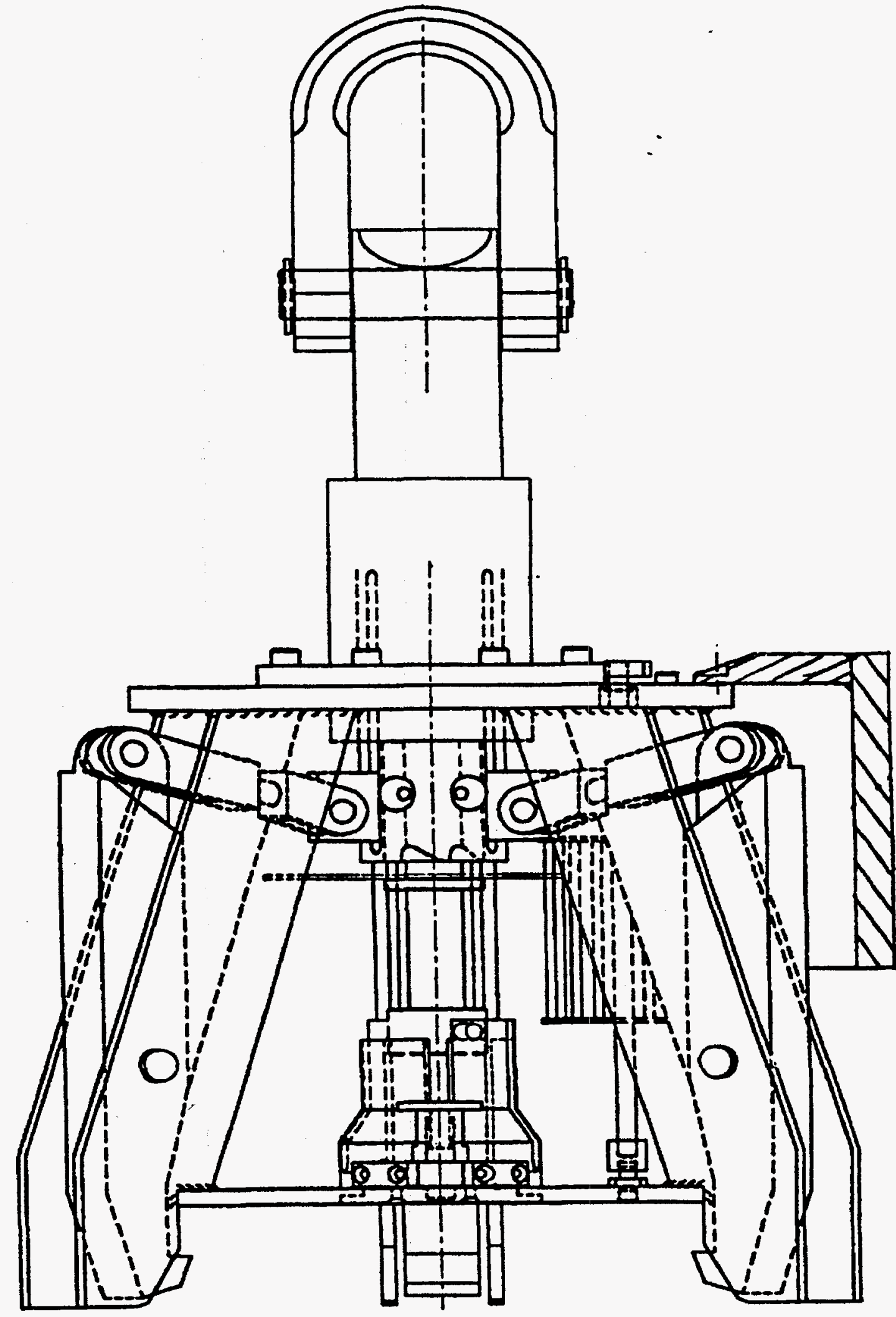

Figure 3.9. Canister Grapple 
The process crane in the Vitrification Cell is a twin-hoist trolley, mounted on a bridge. The bridge span is

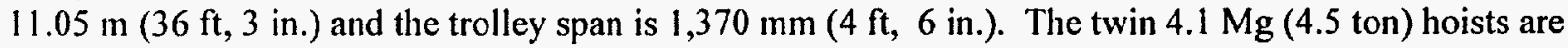

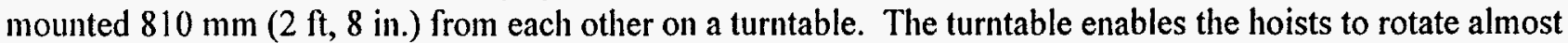
$2 \mathrm{~B}$ radians ( 359 degrees), which allows the hoists to reach closer to the Vitrification Cell walls than would be possible with only a single hoist.

All motions on the crane are two speed and are relatively slow compared to nonremote cranes in order to reduce the possibility of lifting mishaps. The bridge travels at $20 \mathrm{~mm} / \mathrm{s}$ or $60 \mathrm{~mm} / \mathrm{s}(4 \mathrm{ft} / \mathrm{min}$. or $12 \mathrm{ft} / \mathrm{min}$.). The trolley travels at $20 \mathrm{~mm} / \mathrm{s}$ or $60 \mathrm{~mm} / \mathrm{s}(4 \mathrm{ft} / \mathrm{min}$. or $12 \mathrm{ft} / \mathrm{min}$.). The lift rate is $25 \mathrm{~mm} / \mathrm{s} \mathrm{or} 75 \mathrm{~mm} / \mathrm{s}(5$ $\mathrm{ft} / \mathrm{min}$. or $15 \mathrm{ft} / \mathrm{min}$.). The hoist trolley rotates at $0.5 \mathrm{rev} . / \mathrm{min}$. or at $1.5 \mathrm{rev} . / \mathrm{min}$.

\subsection{Glass Shard Sample System}

\subsubsection{Functional Requirements}

The shard sample system is used to collect glass fragments from filled process canisters for archive or for transport to a laboratory for analysis. The results of the analyses are used for feed makeup process quality assurance.

\subsubsection{Process Description}

At the weld station, prior to capping the canisters, a vacuum pick-up assembly is inserted, using manipulators, into the top of an open canister. Air is introduced to an eductor at the top of the sampler that creates a vacuum to draw glass shards against a screen. With the air eductor still operating, the pick-up assembly is moved to a sorter assembly containing a sample vial. With the pick-up assembly over the vial, the air is discontinued, the vacuum is lost, and the glass shards are allowed to fall by gravity into the sorter assembly, which directs the shards into the vial. The vial with the glass shards is transported for archiving or to an analytical laboratory for dissolution and analysis.

\subsubsection{Hardware Description ${ }^{(10)}$}

The shard sampler, shown in Figure 3.10-1, is a stainless steel pipe with an air-operated eductor mounted on one end and a nozzle assembly at the other. The replaceable nozzle assembly has a built-in screen to capture the glass fragments. The assembly also doubles as a glass height indicator (A scale attached to the length of the pipe is used to obtain glass level measurements.). The shard sampler has provisions for being handled with manipulators or with the overhead crane.

The sorter assembly, shown in Figure 3.10-2, is a small framework designed to hold three sample vials. The vials sit under three funnel trays that direct the glass particles into the sample vials. 

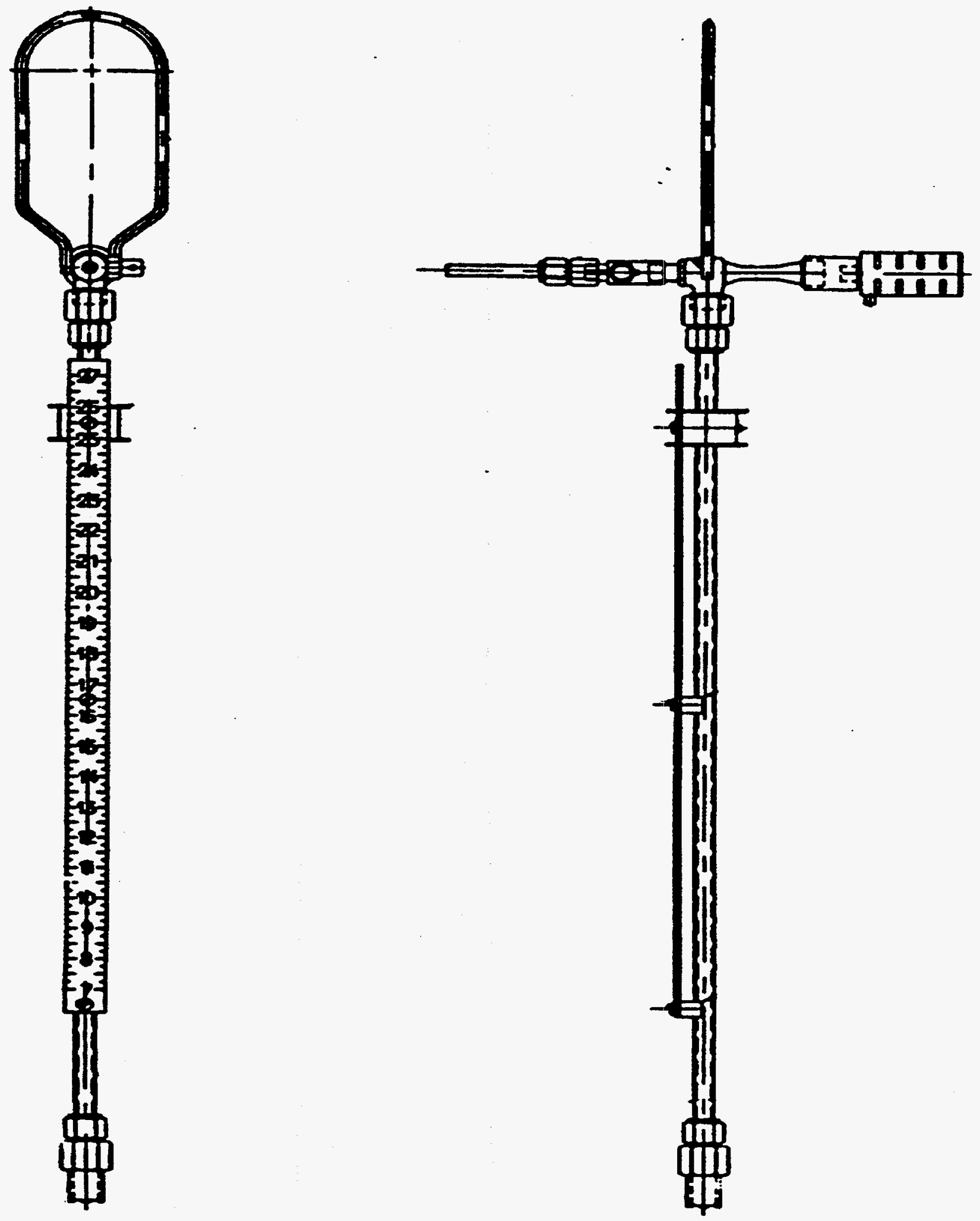

Figure 3.10-1. Glass Shard Sampler 


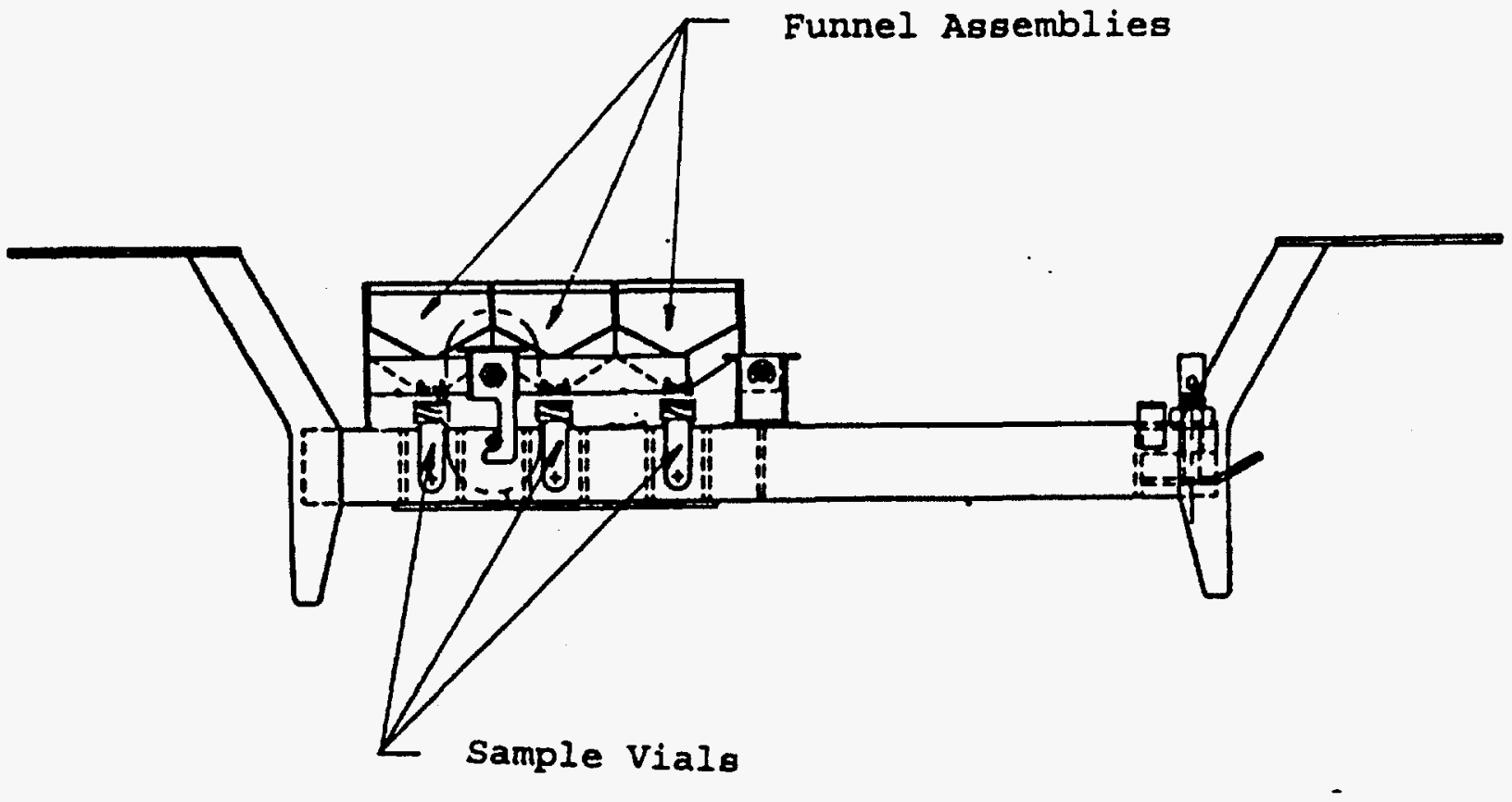

Figure 3.10-2. Sorter Assembly

\subsection{Weld Station}

\subsubsection{Functional Requirements}

The canister lid welding station remotely welds stainless steel covers to the canister flanges.

\subsubsection{Process Description ${ }^{(15)}$}

Lids are welded onto the canister flanges by a remote weld head using an automatic, pulsed-gas tungsten arc welding process. Tools are also available to weld a secondary lid, machine the weld area, and clean the flange.

After lid welding, the canister is transferred by grapple attachment and overhead bridge crane to the decontamination station.

\subsubsection{Hardware Description}

The weld station consists of a stainless steel work bench, the weld head as depicted in Figure 3.11, hoist, flange conditioning tool, lid magazine, vacuum lid lifter, and cover gas supply. The work bench structure measures approximately $3.96 \mathrm{~m}$ long by $1.22 \mathrm{~m}$ wide by $3.66 \mathrm{~m}$ high ( $13 \mathrm{ft} \mathrm{x} 4 \mathrm{ft} \mathrm{x} 12 \mathrm{ft}$ ). It has two canisterholding compartments; one for welding, the other for backup canister storage. Primary lids are held in a lid magazine capable of holding 15 lids. A secondary lid can also be welded onto a canister if the primary weld is unacceptable. The weld head assembly consists of a guide track and support ring about $686 \mathrm{~mm}(2 \mathrm{ft}, 3 \mathrm{in}$.) in diameter, a carriage drive unit, a torch, and a cable assembly. All weld head controls are managed through a welder control console located outside of the Cell. 


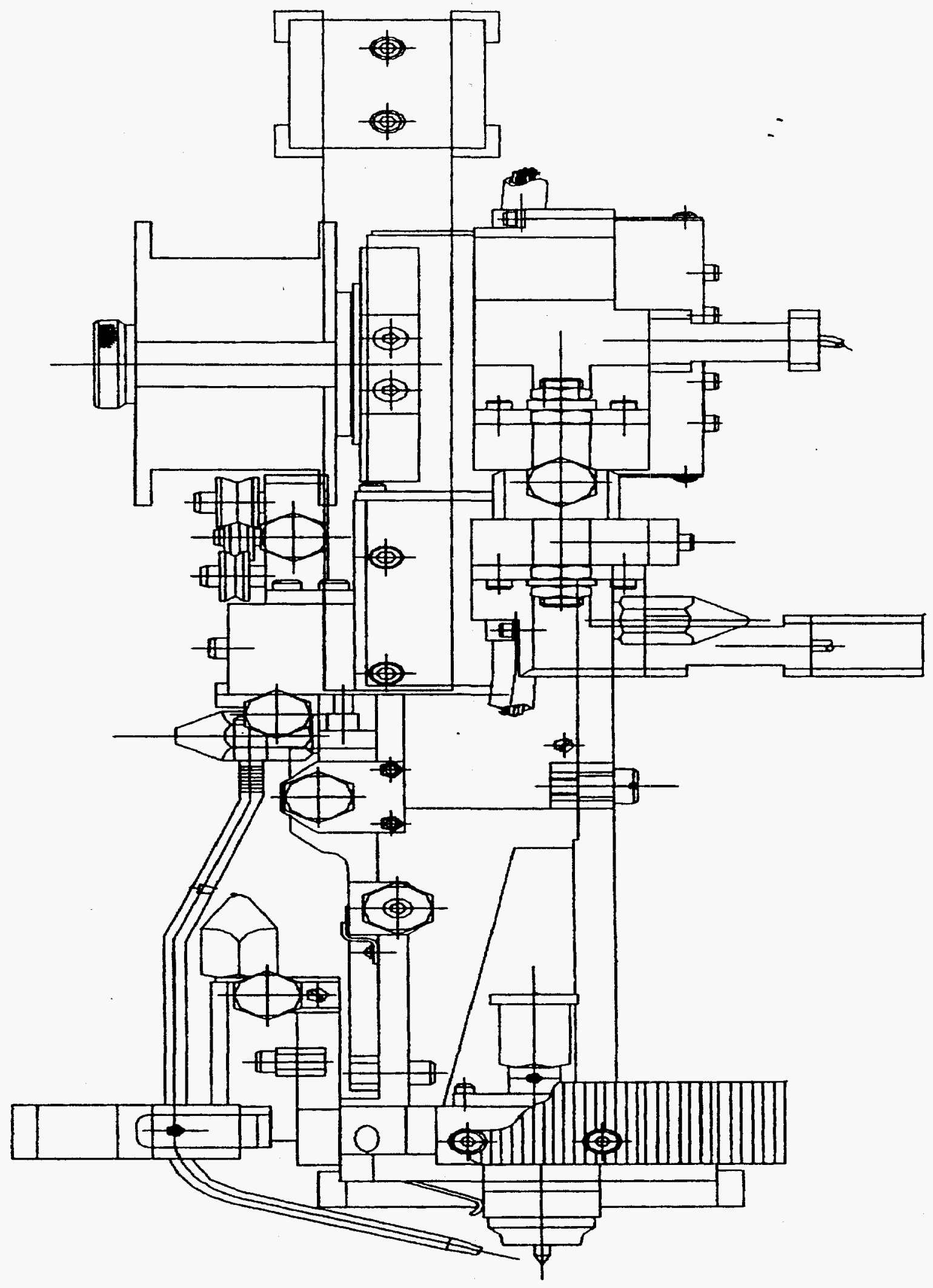

Figure 3.11. Weld Head 


\subsection{Decontamination Station}

\subsubsection{Functional Requirements}

The primary function of the canister decontamination system is to remove radioactive contamination from the canister's exterior surface and to reprocess the removed contamination through the melter.

\subsubsection{Process Description ${ }^{(16)}$}

Nitric acid and a ceric nitrate solution are blended in-line during delivery by gravity flow to a decontamination tank in the Vitrification Cell. Decontamination is achieved by soaking a canister in this solution at $65^{\circ} \mathrm{C}(150$ ${ }^{\circ} \mathrm{F}$ ) for six hours while agitating the solution using a gentle air sparge. Heating the solution is accomplished by delivering steam to coils inside the decontamination tank. The chemical reactions "mill" about $10 \mu \mathrm{m}(33 \mathrm{x}$ $10^{-6} \mathrm{ft}$ ) of material from the canister's surface, according to the following chemical reactions.

$\mathrm{Fe}^{0}+3 \mathrm{Ce}^{+4} 6 \mathrm{Fe}^{+3}+3 \mathrm{Ce}^{+3}$

$\mathrm{Ni}^{0}+2 \mathrm{Ce}^{+4} 6 \mathrm{Ni}^{+2}+2 \mathrm{Ce}^{+3}$

$\mathrm{Cr}^{0}+6 \mathrm{Ce}^{+4} 6 \mathrm{Cr}^{+6}+6 \mathrm{Ce}^{+3}$

The amount of stainless steel removed from the canister is controlled by the concentration of ceric nitrate, temperature of the solution, and residence time in the solution. After soaking in the bath, the canister is rinsed with a dilute nitric acid solution then with demineralized water.

Deactivation of the decontamination solution is accomplished by the addition of hydrogen peroxide that reduces the $\mathrm{Ce}^{+4}$, which attacks stainless steel, to $\mathrm{Ce}^{+3}$, which does not attack stainless steel. Deactivation is accomplished according to the following reaction.

$2 \mathrm{Ce}^{+4}+\mathrm{H}_{2} \mathrm{O}_{2} 62 \mathrm{Ce}^{+3}+2 \mathrm{H}^{+}+\mathrm{O}_{2}$

The decontamination solution is directed by way of the SBS to the CFMT, to be incorporated into the next batch of melter feed slurry.

After decontamination the canister is transferred by grapple attachment and overhead bridge crane to the transfer cart for removal from the Cell.

\subsubsection{Hardware Description}

The decontamination station consists of an out-of-cell station for mixing chemicals, shown in Figure 3.12-1, and the in-cell decontamination station, shown in Figure 3.12-2.

The out-of-cell mix station consists of a nitric acid hold tank and a cerium nitrate charge container. The nitric acid hold tank is fabricated from stainless steel with a $0.757 \mathrm{~m}^{3}$ (200 gal.) capacity. The ceric nitrate solution charge container is fabricated from high-density polyethylene, to resist attack from the $\mathrm{Ce}^{+4}$, and has a capacity of 38 liters ( $10 \mathrm{gal}$.). 
The in-cell station includes a stainless steel support structure and two tanks; one for canister decontamination and the other for "neutralization" (deactivation) of the used decontamination solution.

The decontamination tank is made of titanium for ruggedness and to resist attack by the decontamination solution. The tank is approximately $760 \mathrm{~mm}$ (30 in.) in diameter, with a capacity of $1.55 \mathrm{~m}^{3}$ (410 gal.). The tank equipment includes a sparge ring for agitation of the solution, a level probe, a thermowell to support temperature control, heating and cooling coils, a spray ring for removal of solution residue from the decontaminated canister, and a jet to transfer the used solution to the neutralizer tank.

The neutralizer tank is also made of titanium, is $760 \mathrm{~mm}$ (30 in.) in diameter, and has a capacity of $1.46 \mathrm{~m}^{3}$ (385 gal.). This tank includes a vent to the vent header, sample nozzle, level probe, sparge ring, and jet for transfer of the (deactivated) solution to the SBS. 


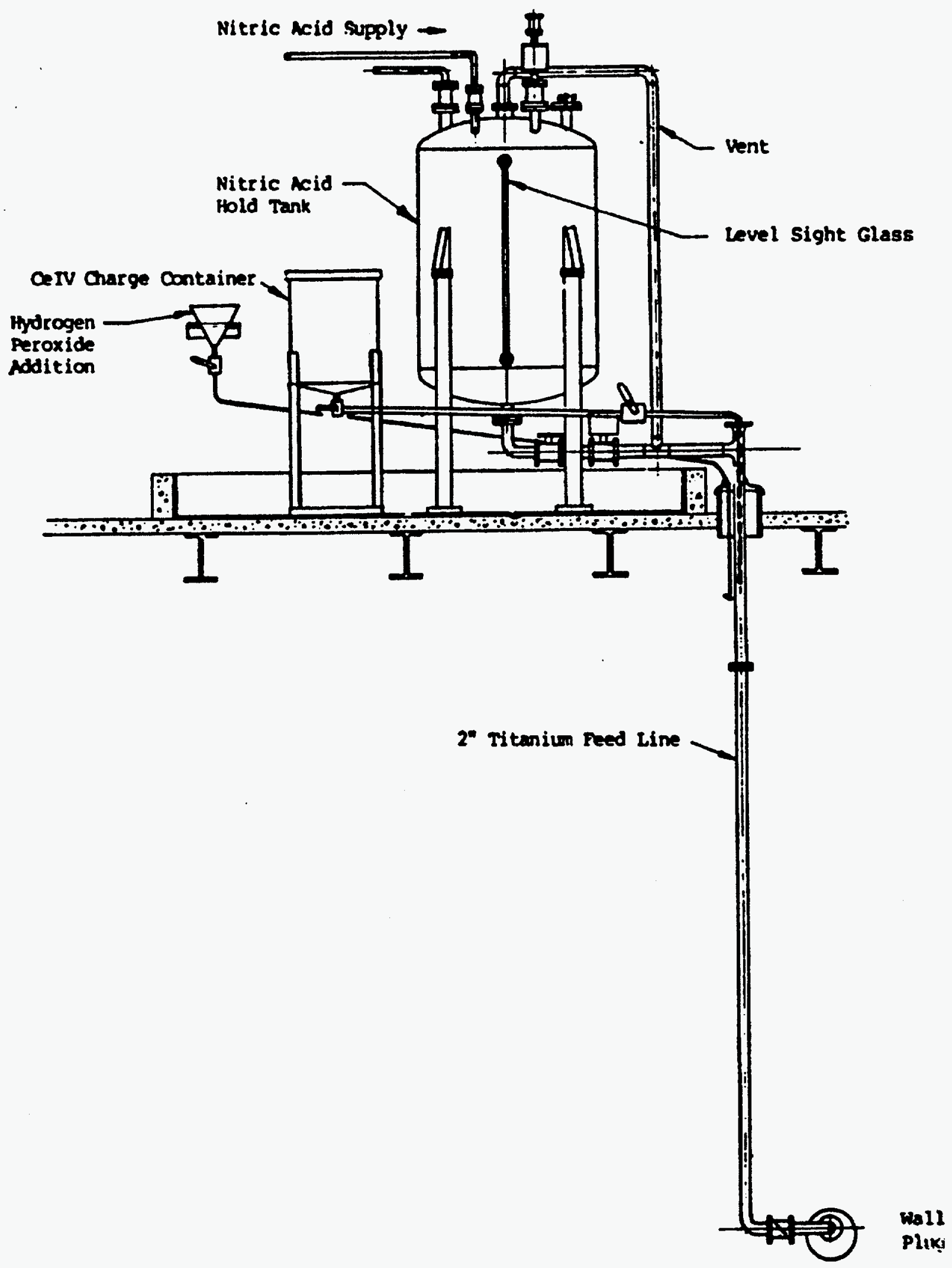

Figure 3.12-1. Decontamination Chemical Mixing Station 


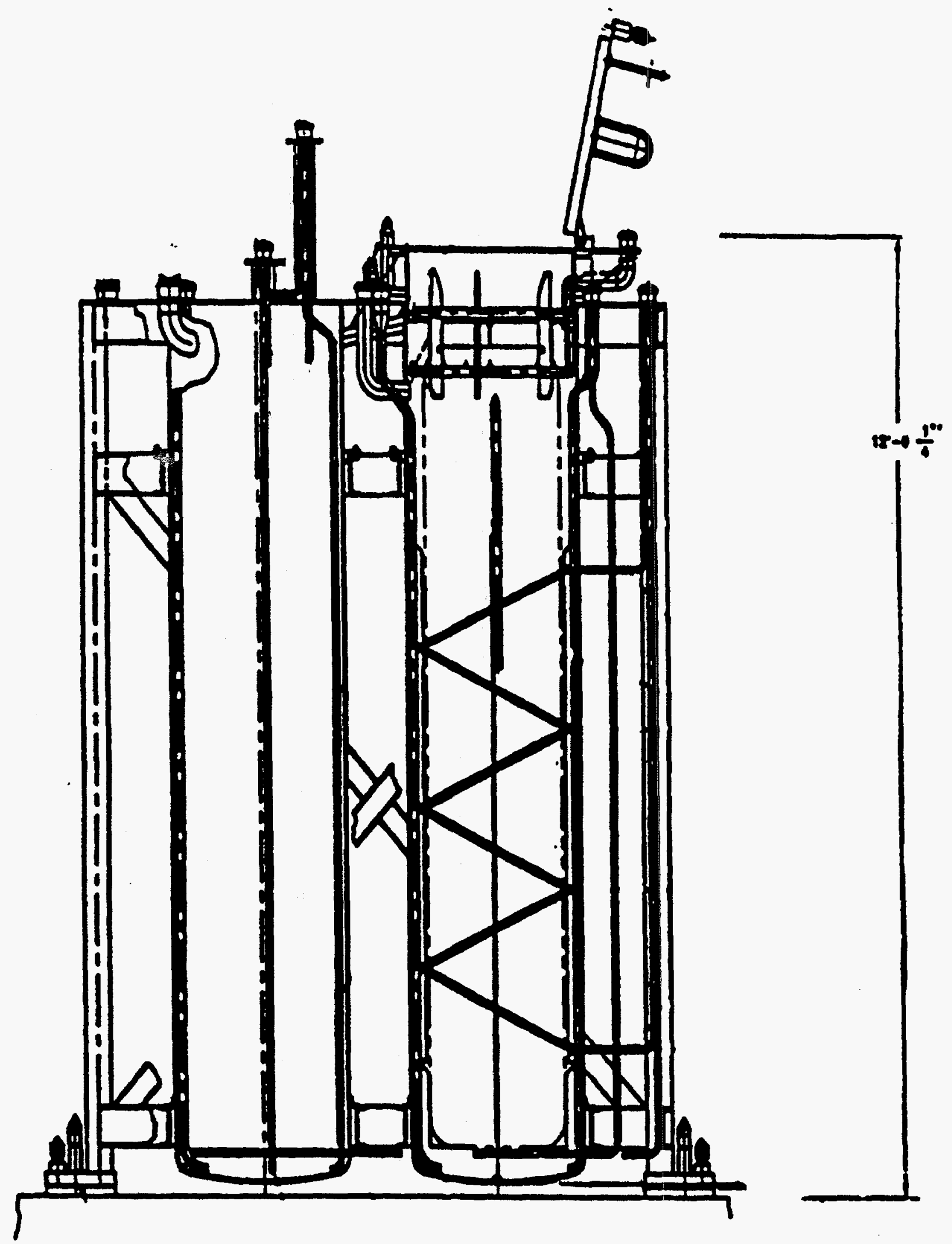

Figure 3.12-2. Decontamination Station 


\subsection{Transfer Cart}

\subsubsection{Functional Requirements}

The primary function of the transfer cart is the movement of filled, capped, and decontaminated canisters from the Vitrification Cell to the High-level Waste Interim Storage Facility.

\subsubsection{Process Description ${ }^{(17)}$}

After decontamination, the canisters are transferred by grapple attachment and overhead bridge crane to a storage rack and, subsequently, to the transfer cart for removal from the Cell. Under operator control, the cart travels on rails through the transfer tunnel and the previously existing Equipment Decontamination Room (EDR) into the High-level Waste Interim Storage Facility, which is the Chemical Processing Cell (CPC) of the former reprocessing plant. There, the canisters are removed from the transfer cart by grapple attachment and overhead bridge crane for placement in a storage rack.

\subsubsection{Hardware Description}

The cart, shown in Figure 3.13, is remote-controlled and battery-powered with four independent drive trains, any one of which can drive the cart forward or reverse, while fully loaded. It was designed to move a load of four, $100 \%$ filled canisters. 


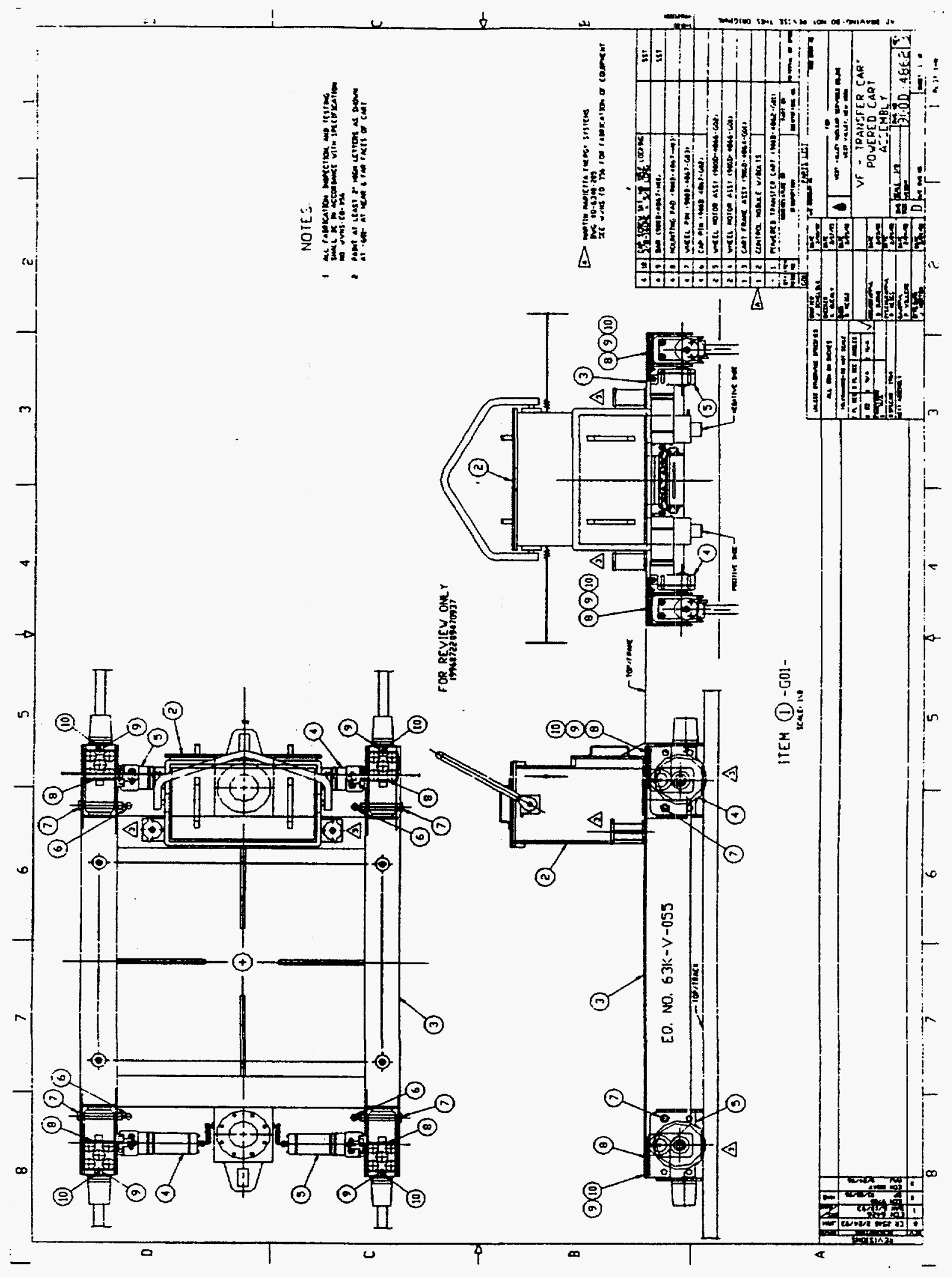

Figure 3.13. Transfer Cart 


\subsection{Waste Header}

\subsubsection{Functional Requirements}

The waste header accepts wastes or overflow from the CFMT, the MFHT, the SBS, the canister decontamination system, and any wastes that spill to the floor of the Vitrification Cell that can be collected at the sumps.

\subsubsection{Process Description ${ }^{(18)}$}

Wastes, as liquids or slurries, are accepted upon demand and are delivered to the Tank Farm by gravity flow.

The waste header was sized to transfer concentrated waste slurry by gravity flow at a rate of $95 \mathrm{l} / \mathrm{min}$. (25 $\mathrm{gpm}$ ). At this flow rate, the waste would generally remain in the bottom half of the header and the flow of the "pseudo-plastic" slurry would be characterized by turbulence. Being only partially filled, the header would not become pressurized so the slurry would not "back-up" to undesired locations. Being turbulent, deposition of solids in the header is "discouraged."

\subsubsection{Hardware Description}

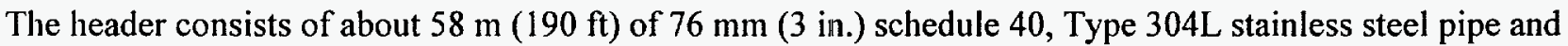
fittings assembled with butt welds, in a branching configuration. It slopes in the direction of the Tank Farm at a rate of $10 \mathrm{~mm} / \mathrm{m}(1 / 8 \mathrm{in} . / \mathrm{ft})$.

\subsection{Vessel Ventilation Equipment}

\subsubsection{Functlonal Requirements}

The vessel vent system is designed to maintain a slight vacuum, about $1 \mathrm{kPa}(5 \mathrm{in}$. WC), on process components. The steam produced by operation of the CFMT is condensed and directed to the Tank Farm.

\subsubsection{Process Description ${ }^{(18)}$}

Ventilation gases and vapors from the CFMT, MFHT, and decontamination station are collected into a single vessel vent header. In the event that vacuum is lost in the melter, gases and vapors from the melter are also directed into the vessel vent header to re-establish the vacuum. The gases and vapors from the vessel vent header are directed into a condenser. The condensate flows by gravity to the Tank Farm for subsequent processing. The gases and uncondensed vapors are directed into the melter off-gas treatment system.

\subsubsection{Hardware Description}

The vessel ventilation header is located on a ledge below the crane rails, near the top of the Vitrification Cell walls. It rests on adjustable supports that allowed installation at a slope of $10 \mathrm{~mm} / \mathrm{m}(1 / 8 \mathrm{in} . / \mathrm{ft})$ so that any 
liquids would drain to the condenser. The header is made from seamless, $150 \mathrm{~mm}$ ( $6 \mathrm{in}$.), schedule 40 , Type 304 stainless steel pipe.

Stresses in the header due to thermal expansion and contraction over the design temperature range are accommodated by six, permanently installed expansion joints made from Type 304L stainless steel. They are protected from physical abuse by external covers, and from accumulations of particulate by internal sleeves.

The header is designed for the following conditions.

$\begin{array}{lll}\text { Temperature } & 13{ }^{\circ} \mathrm{C} \text { to } 260^{\circ} \mathrm{C} & \left(55^{\circ} \mathrm{F} \text { to } 500^{\circ} \mathrm{F}\right) \\ \text { Pressure } & 210 \mathrm{kPa} & (30 \mathrm{psig}) \\ \text { Vacuum } & 30 \mathrm{kPa} & (120 \mathrm{in} . \mathrm{WC})\end{array}$

The vessel ventilation condenser, shown schematically in Figure 3.15 , is a vertical, $3 \mathrm{GJ} / \mathrm{h}\left(3 \times 10^{6} \mathrm{Btu} / \mathrm{hr}\right)$

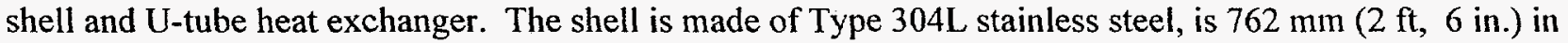
diameter, is $3,400 \mathrm{~mm}(11 \mathrm{ft})$ high, and rests on a $1,200 \mathrm{~mm}(4 \mathrm{ft})$ skirt. The empty shell, with vessel head, weighs $1.8 \mathrm{Mg}\left(3,980 \mathrm{lb}_{\mathrm{m}}\right)$.

The shell is American Society of Mechanical Engineers (ASME) "U" stamped and is designed for the following conditions.

Temperature

Pressure

Vacuum

Pressure Diff. (max.)

Flow (inlet) $185^{\circ} \mathrm{C}$

$210 \mathrm{kPa}$

$30 \mathrm{kPa}$

$7 \mathrm{kPa}$

$45 \mathrm{~m}^{3} / \mathrm{min} .(1,600 \mathrm{acfm})$ $\left(365^{\circ} \mathrm{F}\right)$

(30 psig)

(120 in. WC)

(1 psid)

The tube bundle consists of 343, Type 304L stainless steel, $19 \mathrm{~mm} \mathrm{(3/4} \mathrm{in.)} \mathrm{diameter,} 1.2 \mathrm{~mm}$ thick (18 BWG) tubes in a "U" configuration extending $2,390 \mathrm{~mm}$ ( $7 \mathrm{ft}, 10 \mathrm{in}$.) down from the top flange of the condenser shell. The empty and drained tube bundle weighs $1.28 \mathrm{Mg}\left(2,830 \mathrm{lb}_{\mathrm{m}}\right)$. Two lifting bails are provided on the top of the tube sheet for handling.

The tube bundle head is ASME "U" stamped and the bundle is designed for the following conditions.

Temperature $185^{\circ} \mathrm{C}$

Pressure

Pressure Diff. (max.)

Flow (max.)

$34 \mathrm{kPa}$
$690 \mathrm{kPa}$

$490 \mathrm{l} / \mathrm{min} .(130 \mathrm{gpm})$

$$
\left(365^{\circ} \mathrm{F}\right)
$$

(100 psig)

(5 psid) 


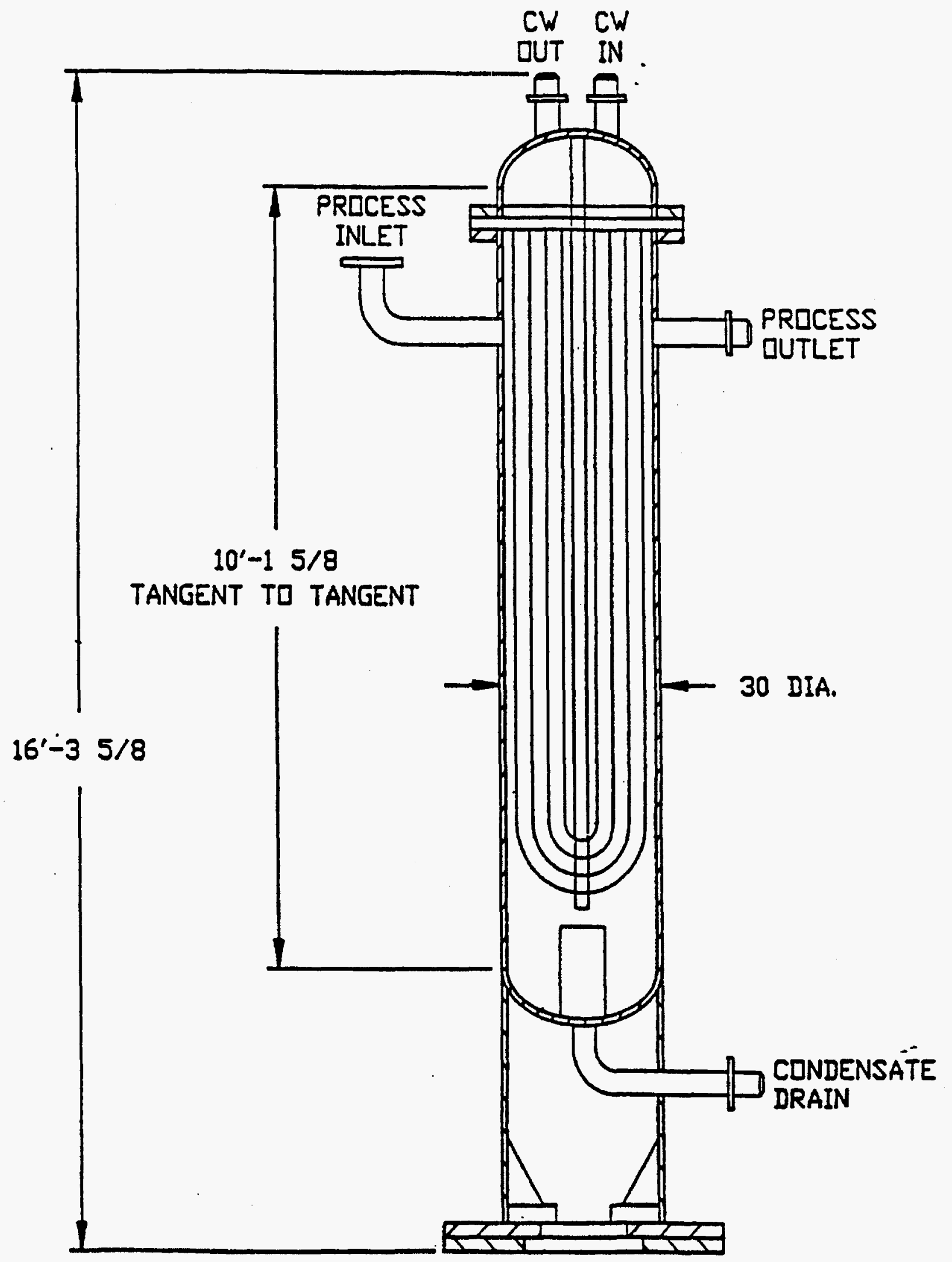

Figure 3.15. Vessel Ventilation Condenser ${ }^{(19)}$ 


\subsection{Submerged Bed Scrubber}

\subsubsection{Functional Requirements}

The primary functions of the Submerged Bed Scrubber (SBS) are quenching and first-stage scrubbing of melter off-gases, cooling and condensation of melter vapor emissions, and interim storage of condensed fluids and spent canister decontamination solution.

\subsubsection{Process Description ${ }^{(19)}$}

The SBS uses water to remove particulate and to quench the off-gases. It functions by bubbling the off-gases through water in a bed packed with ceramic spheres. The packing breaks larger bubbles into smaller ones to increase the gas-to-water contacting surface, thereby increasing the particulate removal and heat transfer efficiencies. The liquid circulation that is induced by the rising off-gases helps to prevent a buildup of captured material in the bed by constantly washing the material away. As the off-gases cool, water vapor condenses and increases the liquid water inventory. The excess water spills out into the receiver, thereby maintaining a constant liquid depth in the scrubber section. Heat absorbed by the water from the off-gases is removed by cooling coils.

To transfer solids to the CFMT, water is first withdrawn from the receiver then re-injected through nozzles near the bottom of the scrubber to scour the bottom and create a swirling motion. The swirling is designed to draw the undissolved solids to the center of the bottom. A jet, with the suction head located over the center of the bottom, is designed to transfer both liquid and accumulated solids to the CFMT.

Transfers to the Tank Farm are made in a similar fashion, but the withdrawal point is from the bottom of the receiver section where fewer undissolved solids accumulate.

\subsubsection{Hardware Description}

The SBS, shown in Figure 3.16, consists of two concentric, right cylindrical vessels made from $9.5 \mathrm{~mm}$ (3/8 in.) Hastelloy $\mathrm{C}-22^{\mathrm{TM}}$. Hastelloy $\mathrm{C}-22^{\mathrm{TM}}$ was selected to resist pitting and crevice attack from mercury that may appear as vapor arriving from the melter and accumulate as liquid.

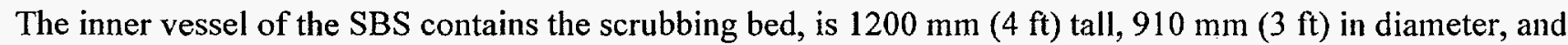
is constantly flooded with water. The bed contains $0.51 \mathrm{~m}^{3}\left(18 \mathrm{ft}^{3}\right)$ of $9.5 \mathrm{~mm}(3 / 8 \mathrm{in}$.) ceramic spheres. An Inconel $690^{\mathrm{TM}}$ bed support/gas distributor plate forms the bottom of the bed (Inconel $690^{\mathrm{TM}}$ was selected for corrosion resistance to the high-temperature off-gases.). Off-gases are introduced through a $250 \mathrm{~mm}$ (10 in.) diameter Inconel $690^{\mathrm{TM}}$ pipe entering from the top and discharging at the bottom of the bed. The outer vessel of the scrubbing section is $1,640 \mathrm{~mm}\left(5 \mathrm{ft}, 4 \mathrm{in}\right.$.) tall by $1,830 \mathrm{~mm}(6 \mathrm{ft})$ in diameter with a capacity of $3.3 \mathrm{~m}^{3}$ ( $880 \mathrm{gal}$.) when the bed is installed. The bottom of the vessel is solid and is dished-shaped to facilitate evacuation by jet transfer. Cooling coils are positioned inside the vessel but outside the packed bed.

The outermost vessel is the SBS receiver vessel. It has a maximum operating volume of $5.5 \mathrm{~m}^{3}(1,450$ gal.), enough to hold all condensation anticipated for one melter waste feed preparation cycle. It is a right cylindrical vessel, $2,440 \mathrm{~mm}(8 \mathrm{ft})$ in diameter and $3,350 \mathrm{~mm}(11 \mathrm{ft})$ tall, with a dished bottom to allow near complete evacuation by jet transfer. It is fabricated from Hastelloy $\mathrm{C}-22^{\mathrm{TM}}$ and has a half-pipe jacket to cool the fluid below $40{ }^{\circ} \mathrm{C}\left(104^{\circ} \mathrm{F}\right)$ before jet transfer. 
The SBS vessel was designed for the following conditions and is ASME code stamped.

Temperature $300{ }^{\circ} \mathrm{C}$

$\left(572^{\circ} \mathrm{F}\right)$

Pressure

$40 \mathrm{kPa}$

(6 psig)

Vacuum

$25 \mathrm{kPa}$

$(100$ in. WC $)$

The heat exchange piping was designed for $550 \mathrm{kPa}(80 \mathrm{psig})$. 


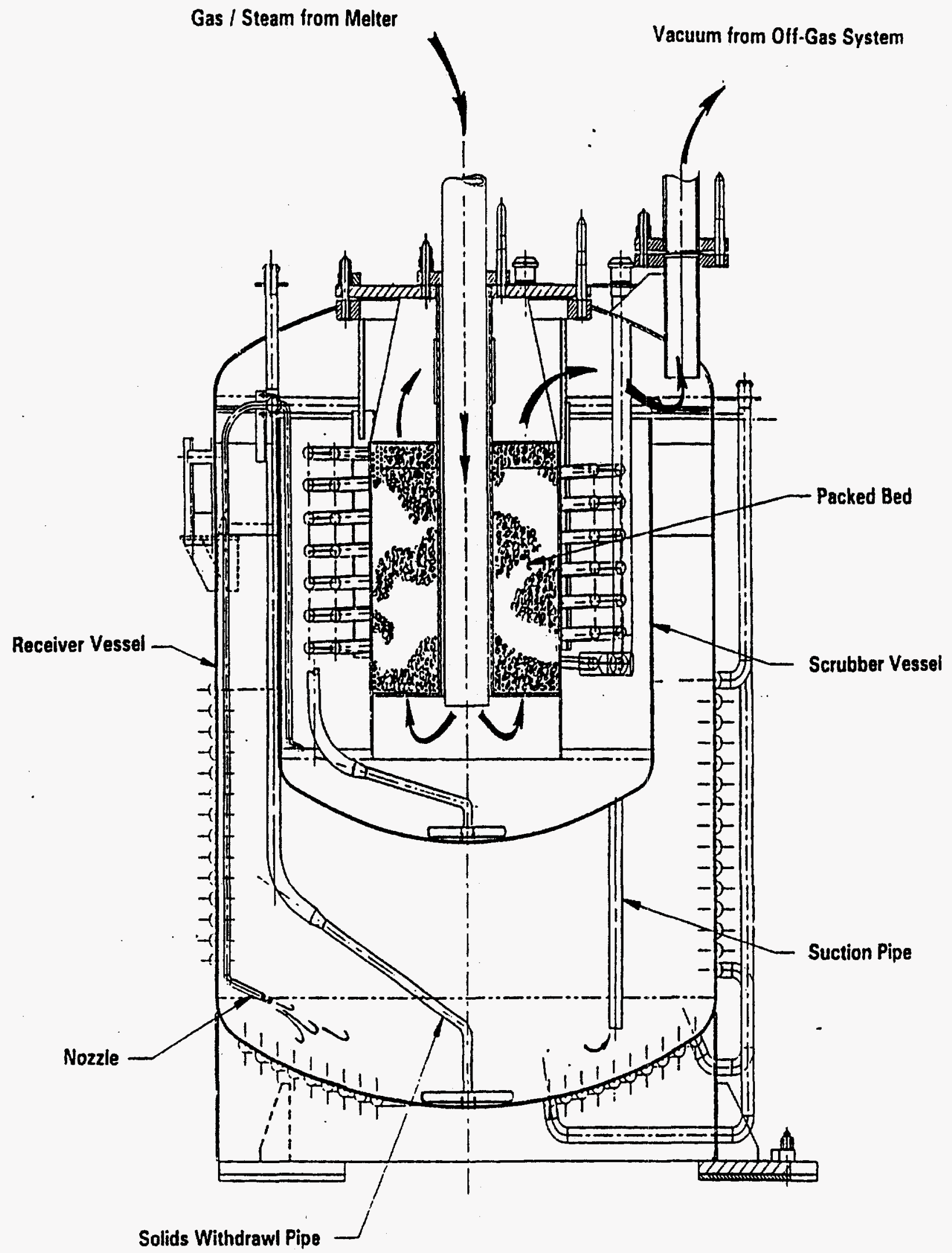

Figure 3.16. Submerged Bed Scrubber ${ }^{(20)}$ 


\subsection{Mist Ellminator}

\subsubsection{Functional Requirements}

The mist eliminator pretreats the off-gas to prevent excessive liquid loading at the high-efficiency mist eliminator (HEME), located downstream.

\subsubsection{Process Description ${ }^{(19)}$}

Off-gases enter from below the pad and exit from above. The mist eliminator pad collects entrained droplets by impaction against the pad fibers where the droplets adhere and coalesce. The coalesced liquid flows by gravity back into the SBS.

\subsubsection{Hardware Description}

The mist eliminator housing, shown in Figure 3.17, is mounted directly on the off-gas exit of the SBS. It is made from $460 \mathrm{~mm}$ (18 in.), schedule 40, Type $304 \mathrm{~L}$ stainless steel pipe, with inlet and outlet ducting made from $150 \mathrm{~mm}$ ( $6 \mathrm{in}$.) pipe. The liquid return line is $25 \mathrm{~mm}$ (1 in.) flex hose that delivers the accumulated liquid back to the SBS at a separate nozzle.

The pad is a $152 \mathrm{~mm}$ ( 6 in.) thick, knitted-mesh pad with a $356 \mathrm{~mm}$ (14 in.) diameter exposed face. It is made from Type $304 \mathrm{~L}$ stainless steel wire and structurals. The pad is designed to minimize fouling and consists of four pads in series, with each successive pad having a greater packing density varying from $53 \mathrm{~kg} / \mathrm{m}^{3}(3.3$ $\left.\mathrm{lb}_{\mathrm{m}} / \mathrm{ft}^{3}\right)$ to $173 \mathrm{~kg} / \mathrm{m}^{3}\left(10.8 \mathrm{lb}_{\mathrm{m}} / \mathrm{ft}^{3}\right)$. The design face velocity is $2.4 \mathrm{~m} / \mathrm{s}(8 \mathrm{ft} / \mathrm{sec}$. $)$.

The mist eliminator bears an ASME "U" stamp and is designed for the following conditions.

$\begin{array}{lll}\text { Temperature } & 121^{\circ} \mathrm{C} & \left(250^{\circ} \mathrm{F}\right) \\ \text { Pressure } & 207 \mathrm{kPa} & (30 \mathrm{psig}) \\ \text { Vacuum } & 30 \mathrm{kPa} & (120 \mathrm{in} . \mathrm{WC})\end{array}$




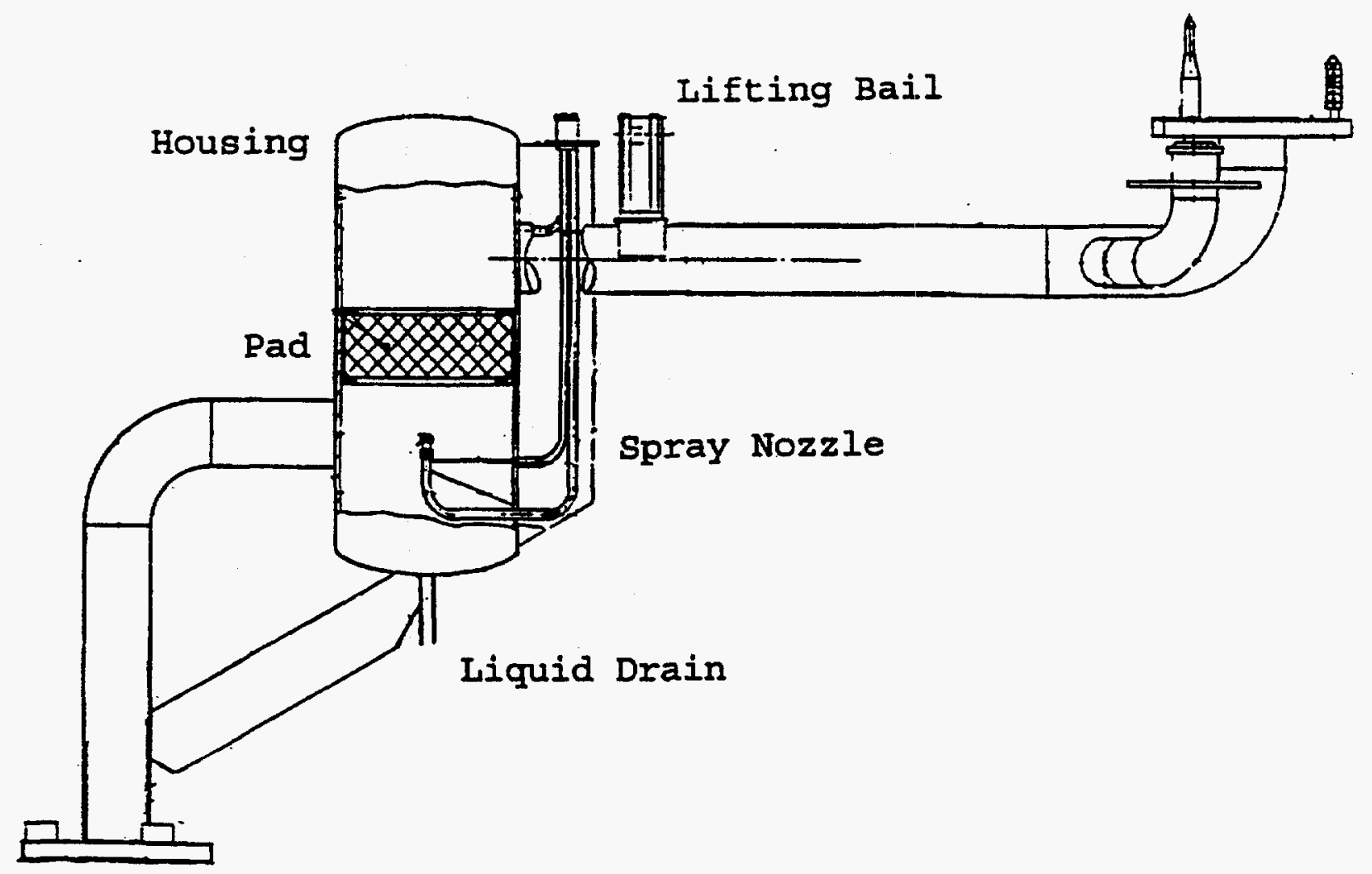

Figure 3.17. Mist Eliminator ${ }^{(20)}$ 


\subsection{High-efficiency Mist Ellminators}

Two HEMEs are installed; one in each of two parallel, off-gas trains.

\subsubsection{Functional Requlrements}

The HEME collects and coalesces entrained liquid droplets to prevent moisture buildup on the prefilter elements downstream, while simultaneously removing additional particulate from the off-gas stream.

\subsubsection{Process Description ${ }^{(19)}$}

Off-gases enter the center of the cylindrical pad from the top and passes through the pad to the outside. The pad is large, so the velocity of the gas through the pad is slow, which allows Brownian movement to bring droplets and particles into contact with the fibers of the pad where they collect and coalesce. The coalesced liquid flows by gravity to the HEME drain, carrying collected particulate with it. The drain lines direct the coalesced liquids back to the SBS.

\subsubsection{Hardware Descrlptions}

The HEME is shown schematically in Figure 3.18.

The vessel is a cylinder $1,070 \mathrm{~mm}(3 \mathrm{ft}, 6 \mathrm{in}$.) in diameter, $4,060 \mathrm{~mm}(13 \mathrm{ft}, 4 \mathrm{in}$.) tall. It is made from Type 304L stainless steel to resist attack from the acidic off-gases. It bears an ASME "U" stamp and is designed for the following conditions.

$\begin{array}{lll}\text { Temperature } & 121^{\circ} \mathrm{C} & \left(250^{\circ} \mathrm{F}\right) \\ \text { Pressure } & 280 \mathrm{kPa} & (40 \mathrm{psig}) \\ \text { Vacuum } & 30 \mathrm{kPa} & (120 \mathrm{in} . \mathrm{WC})\end{array}$

The pad is $760 \mathrm{~mm}(2 \mathrm{ft}, 6 \mathrm{in}$.) in diameter, $3,050 \mathrm{~mm}(10 \mathrm{ft})$ tall, with a wound glass fiber element. The pad, which can be remotely removed and replaced, is enclosed by a woven screen of Type 316L stainless steel. 


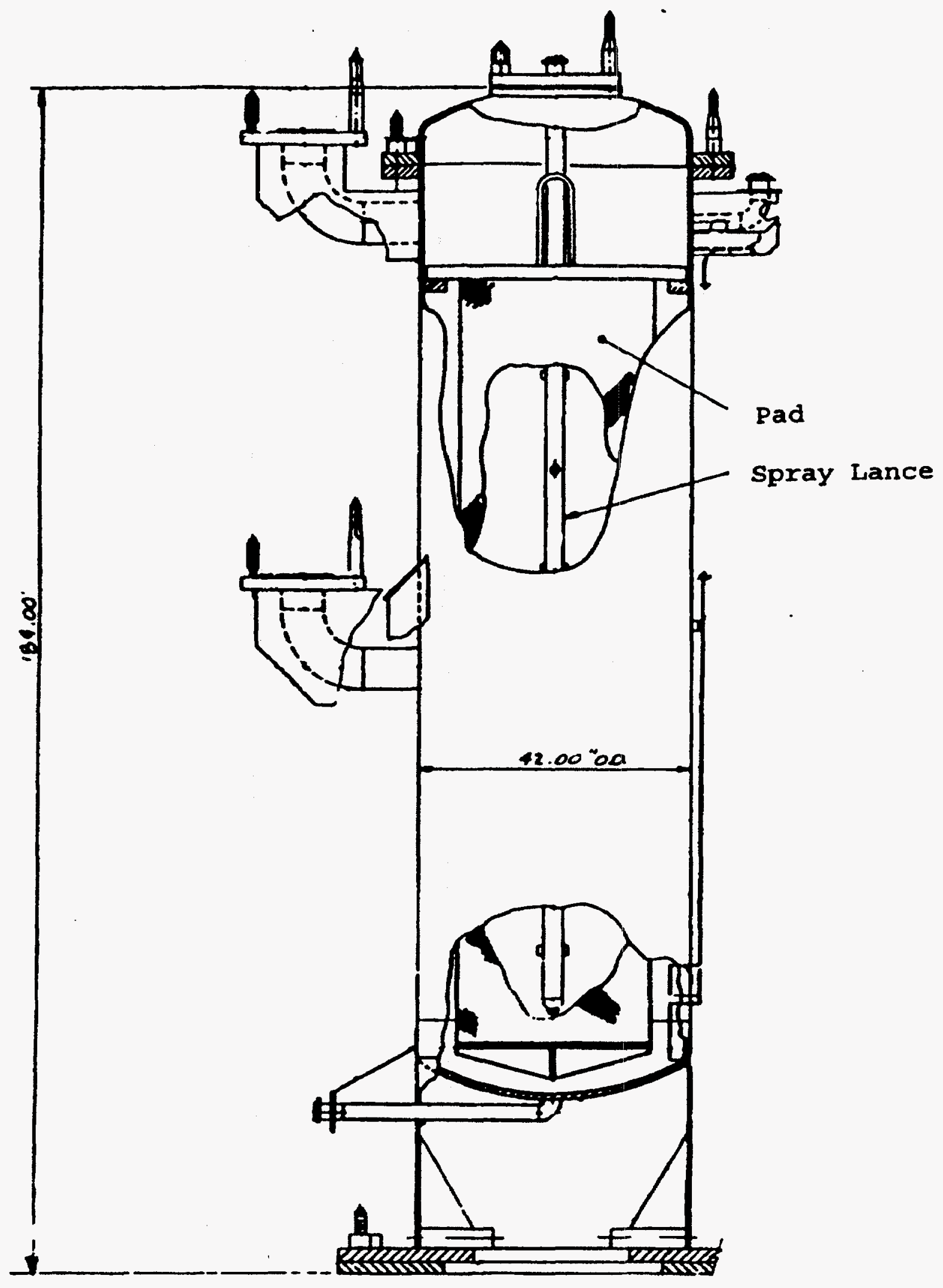

Figure 3.18. High-efficiency Mist Eliminator 


\subsection{Filter Preheater}

Two redundant preheaters are installed; one in each of two parallel, off-gas trains.

\subsubsection{Functional Requirements}

The preheater is required to elevate the temperature of the off-gas to above its dew point to assure that no condensation occurs on the prefilter elements immediately downstream.

\subsubsection{Process Descriptlon ${ }^{(19)}$}

The off-gas from the HEME located immediately upstream arrives saturated with moisture. The preheater converts electrical energy to thermal energy to elevate the temperature of the off-gas, in a controlled manner, to well above the off-gas dew point, but well below the design temperature of the prefilter elements located immediately downstream. During normal steady state operation, about $20 \mathrm{~kW}$ of electrical energy is required to maintain an exit temperature of $85^{\circ} \mathrm{C}\left(185^{\circ} \mathrm{F}\right)$.

\subsubsection{Hardware Descriptions}

The preheater housing, shown in Figure 3.19, is made from Type 304L stainless steel to resist corrosion from the acidic off-gases. It bears an ASME "U" stamp and is designed for the following conditions.

Temperature $121^{\circ} \mathrm{C}$

$\left(250^{\circ} \mathrm{F}\right)$

Pressure

$280 \mathrm{kPa}$

(40 psig)

Vacuum

$30 \mathrm{kPa}$

(120 in. WC)

The preheater element is a $50 \mathrm{~kW}$, electrical-resistance heating element bundle operated with $480-\mathrm{Volt}$, 3phase electrical energy, and is sheathed in Incoloy ${ }^{\mathrm{TM}}$ for high temperature corrosion resistance. 


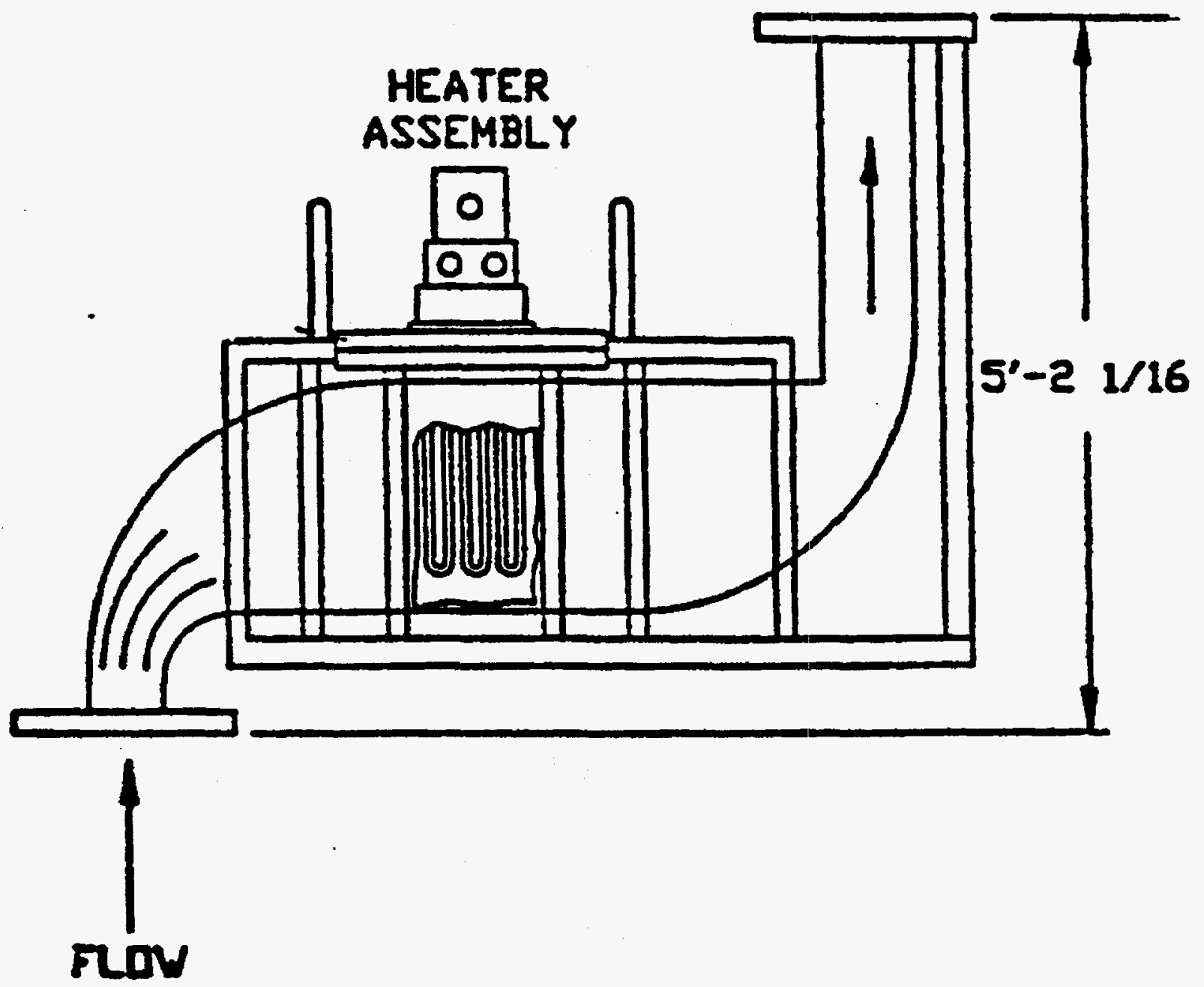

Figure 3.19. Filter Preheater 


\subsection{Prefilter}

Two prefilter assemblies are installed; one in each of two parallel, off-gas trains.

\subsubsection{Functional Requirements}

The primary function of the prefilters is to prevent significant contamination from reaching off-gas treatment equipment located downstream, outside the Vitrification Cell, thereby allowing hands-on maintenance there.

\subsubsection{Process Description ${ }^{(19)}$}

The prefilter assemblies passively capture dry particulate from the off-gases passing through them.

Filter change-out is accomplished by removal and replacement of the entire prefilter assembly, which includes the housing and two HEPA elements arranged in series. Replacement prefilter assemblies are tested prior to introduction into the Vitrification Cell to assure that no perforations are in the filter media, and that no breaks are in the seal between the filter elements and the housing.

\subsubsection{Hardware Descriptions}

Each prefilter assembly, shown in Figure 3.20, consists of a housing made from Type 304L stainless steel for resistance to corrosion from the acidic off-gas, a perforated flow straightening baffle, and two HEPA filter elements in series. The baffle is a rectangular sheet with 390 uniformly spaced $19 \mathrm{~mm}(3 / 4 \mathrm{in}$.) diameter holes. The elements are fiberglass.

The prefilter assemblies bear ASME "U" stamps and are designed for the following conditions.

Temperature $121^{\circ} \mathrm{C}$

$\left(250^{\circ} \mathrm{F}\right)$

Pressure $\quad 280 \mathrm{kPa} \quad(40 \mathrm{psig})$

Vacuum $\quad 30 \mathrm{kPa} \quad(120 \mathrm{in.} \mathrm{WC})$

Flow, maximum

$42 \mathrm{~m}^{3} / \mathrm{min}$

$(1,500 \mathrm{acfm})$ 


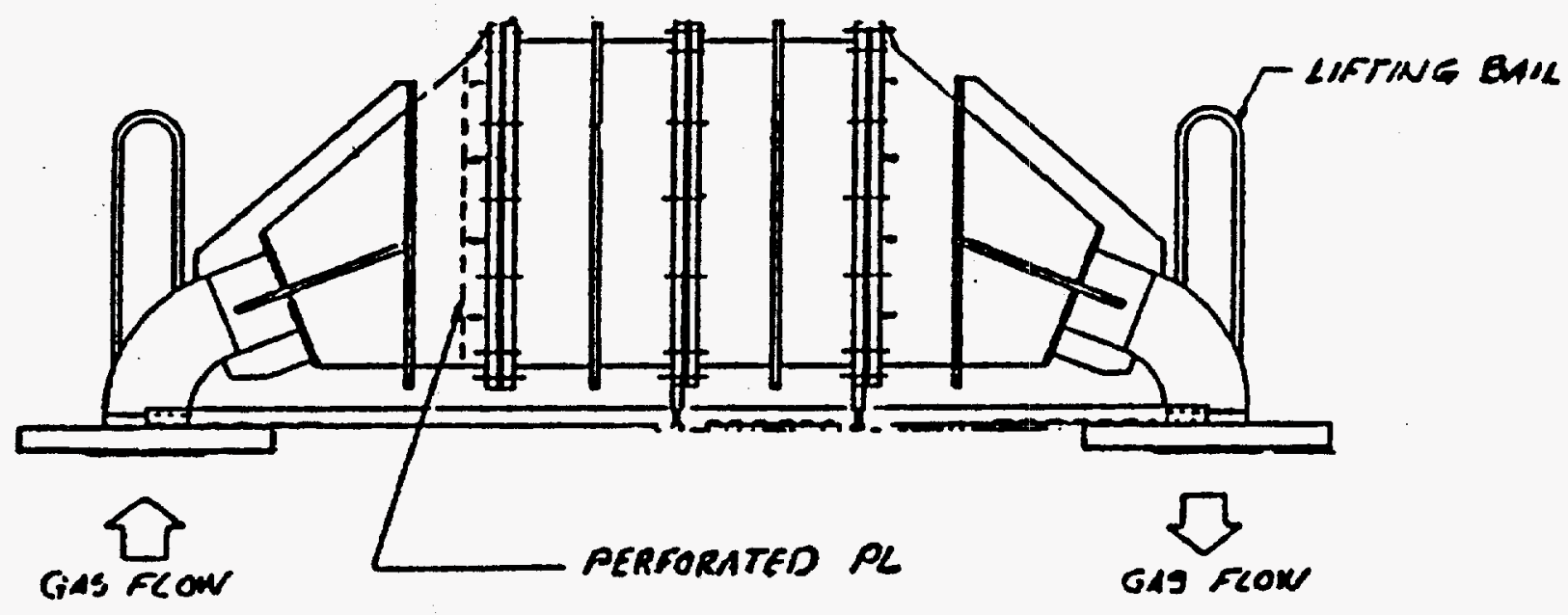

ELEVATION

Figure 3.20. Prefilter

54 


\subsection{Reheater}

Two redundant, off-gas reheaters are connected in parallel.

\subsubsection{Functional Requirements}

The prefiltered off-gas from the Vitrification Cell is directed through an insulated duct to another building for additional treatment, including HEPA filtration, prior to release. While in the duct the off-gas is expected to cool. The primary function of the reheater is to restore the temperature of the off-gas to above its dew point.

\subsubsection{Process Description ${ }^{(21)}$}

The off-gas arriving from the duct in the trench may have cooled to below its dew point. The reheater converts electrical energy to thermal energy to elevate the temperature of the off-gas, in a controlled manner, to well above the off-gas dew point, but well below the design temperature of the HEPA filter elements located immediately downstream. During normal steady state operation, about $10-15 \mathrm{~kW}$ of electrical energy is required to maintain an exit temperature of $85^{\circ} \mathrm{C}\left(185^{\circ} \mathrm{F}\right)$.

\subsubsection{Hardware Descriptions}

The reheater housing, shown in Figure 3.21, is made from $250 \mathrm{~mm}$ (10 in.) diameter pipe of Type 304L stainless steel to resist corrosion from the acidic off-gas. The housings are insulated to limit the temperature of exposed surfaces to $60^{\circ} \mathrm{C}\left(140^{\circ} \mathrm{F}\right)$. Each housing is ASME code stamped and is designed for the following conditions.

Temperature $\quad 400^{\circ} \mathrm{C}$

Pressure $\left(750^{\circ} \mathrm{F}\right)$

(90 psig)

The reheater element is a $60 \mathrm{~kW}$, electrical-resistance immersion heating element bundle operated with 480 Volt, 3-phase, electrical energy and is sheathed in Incoloy $800^{\mathrm{TM}}$ for high temperature corrosion resistance. 


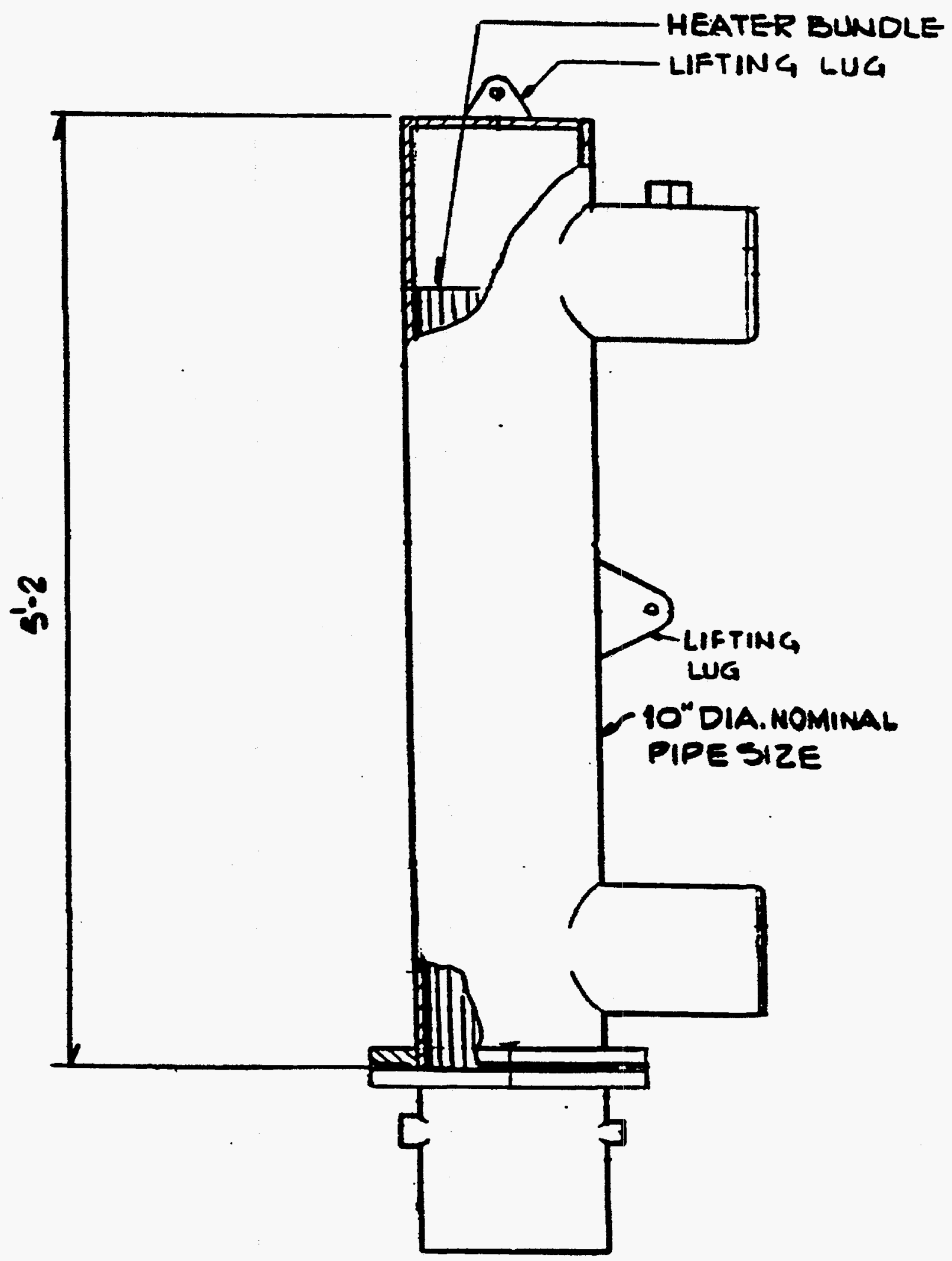

Figure 3.21. Reheater 


\subsection{Final High-efficlency Particulate Air (HEPA) Filters}

Two redundant HEPA filter trains are installed in parallel; both in the same housing.

\subsubsection{Functional Requirements}

The purpose of the HEPA filters is to provide final atmospheric protection against dispersion of radioactive particulate.

\subsubsection{Process Description ${ }^{(21)}$}

The HEPA filter elements are each $99.97 \%$ efficient for retaining particles $0.3 \mu \mathrm{m}\left(1 \times 10^{-6} \mathrm{ft}\right)$ in diameter. For particles $0.3 \mu \mathrm{m}$ and larger, capture is by impaction. For particles $0.1 \mu \mathrm{m}$ and smaller, capture is by Brownian motion.

The integrity of the filter elements, and the seals between the elements and the housing, is verified by in-place testing with dioctyl phthalate (DOP) challenge aerosol.

\subsubsection{Hardware Descriptions}

Both parallel HEPA filter trains, consisting of two HEPA filter elements in series, are contained in a common housing made from $6 \mathrm{~mm}$ (1/4 in.) Type 304L stainless steel plate. The housing, shown in Figure 3.22, accommodates filter elements $610 \mathrm{~mm}$ by $610 \mathrm{~mm}$ by $290 \mathrm{~mm}$ deep ( 24 in. $x 24$ in. x 11-1/2 in.). The filter elements are held in place by air piston actuated, remotely operated, clamping devices. Off-gas enters from the bottom of the housing, passes horizontally through two filter elements, then exits from the top of the housing. Each filter element position has a bag-out port. Each of the bag-out ports is located behind a $150 \mathrm{~mm}(6 \mathrm{in}$.) thick carbon steel shield door. Each shield door is mounted on two steel wheels and can move along a horizontal rail by use of an air cylinder. 


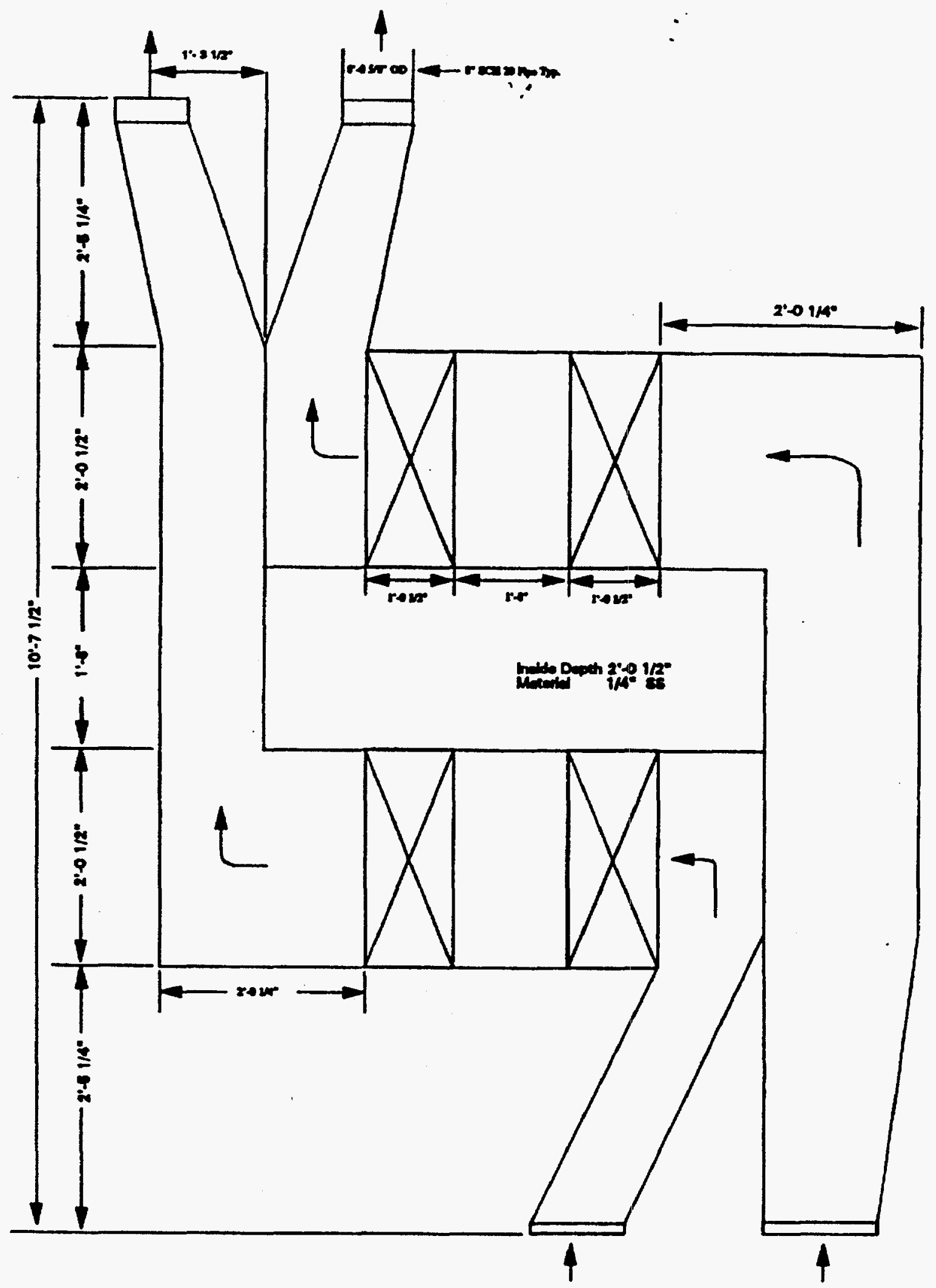

Figure 3.22. Final HEPA Filters 


\subsection{Blowers}

Three blowers are installed in parallel. This allows one to be in-service and another to be available on stand-by while one is out-of-service for maintenance.

\subsubsection{Functional Requirements}

The operating blower provides the motive force to maintain all of the vitrification equipment upstream under a slight vacuum for contamination control. It also provides the motive force to discharge the treated off-gas to the atmosphere.

\subsubsection{Process Description ${ }^{(21)}$}

One of the three blowers operates continuously.

The vacuum setting at the blower suction is selected to be greater than the minimum required to maintain the melter at the desired vacuum, taking into account the pressure differentials across the equipment in the off-gas system. Control of the vacuum to the designated set-point is accomplished by automatic modulation of air inbleed into the blower suction line.

\subsubsection{Hardware Description}

The blowers are rotary, positive displacement, lobe-style blowers sized for $42.5 \mathrm{~m}^{3} / \mathrm{min}$. $(1,500 \mathrm{acfm})$ flow at the blower inlet, with the off-gas at $-25 \mathrm{kPa}(100 \mathrm{in}$. WC vacuum $)$ and $82^{\circ} \mathrm{C}\left(180^{\circ} \mathrm{F}\right)$. They are controlled by adjustable frequency drives designed to operate at only two set points, and are normally operated at a speed to motivate about $27 \mathrm{~m}^{3} / \mathrm{min}$. (950 acfm).

The motors directly coupled to the blowers are $56 \mathrm{~kW}(75 \mathrm{hp})$, totally enclosed, fan-cooled, variable-speed, 3 phase, 460-Volt electric induction motors.

\subsection{4 $\mathrm{NO}_{\mathrm{x}}$ Abatement Equipment}

Two catalytic $\mathrm{NO}_{x}$ converters are installed in parallel. One is used while the other is available on stand-by.

\subsubsection{Functional Requirements}

The purpose of the $\mathrm{NO}_{\mathrm{x}}$ abatement equipment is to destroy the noxious oxides of nitrogen, $\mathrm{NO}$ and $\mathrm{NO}_{2}$, in order to comply with the discharge limits imposed by the state regulatory authority.

\subsubsection{Process Description ${ }^{(21)}$}

The $\mathrm{NO}_{\mathrm{x}}$ converters employ selective catalytic reduction to destroy undesirable $\mathrm{NO}_{\mathrm{x}}$ gases by converting them to harmless water vapor, nitrogen, and oxygen. The $\mathrm{NO}_{\mathrm{x}}$ destruction equipment includes redundant off-gas 
preheaters, an ammonia supply system, and redundant catalytic converters. The preheaters increase the off-gas temperature to about $320^{\circ} \mathrm{C}\left(610^{\circ} \mathrm{F}\right)$ to promote the desired reaction. The ammonia supply provides the necessary reactant and the catalyst in the catalytic converter accelerates the desired reaction.

\subsubsection{Hardware Descriptions}

An on-line, nondispersive infrared, $\mathrm{NO}_{\mathrm{x}}$ analyzer is used to sense the amount of $\mathrm{NO}_{\mathrm{x}}$ approaching the $\mathrm{NO}_{\mathrm{x}}$ abatement system and control the amount of ammonia reactant to be added to the off-gas as it approaches the catalytic converter. Another analyzer is used to detect the amount of $\mathrm{NO}_{\mathrm{x}}$ exiting the catalytic converter for $\mathrm{NO}_{\mathrm{x}}$ release reporting.

Two redundant $\mathrm{NO}_{\mathrm{x}}$ abatement system preheater trains consist of two electric heaters arranged in series. Each heater assembly includes a $3,100 \mathrm{~mm}$ (10 ft, $2 \mathrm{in}$.) tall, $300 \mathrm{~mm}$ (12 in.) in diameter, Type 304L stainless steel housing and a removable immersion heating element bundle. Each housing, shown in Figure 3.24-1, is insulated to maintain the temperature of exposed surfaces below $60^{\circ} \mathrm{C}\left(140^{\circ} \mathrm{F}\right)$. Each element bundle is rated at $101 \mathrm{~kW}$ for 480 -Volt, 3-phase, electrical energy, and consists of forty-eight, Incoloy 800 sheathed, $12 \mathrm{~mm}$ (0.475 in.) diameter elements.

The catalytic converter vessels, depicted in Figure 3.24-2, are right cylinders, made from $6 \mathrm{~mm}$ (1/4 in.) thick, Type 321 stainless steel, with the inlet at the conical top and the outlet at the conical bottom. The overall height of each catalytic converter assembly is $4,290 \mathrm{~mm}$ ( $14 \mathrm{ft}, 1 \mathrm{in}$.). The cylindrical sections have outside diameters of $1,020 \mathrm{~mm}$ ( $3 \mathrm{ft}, 4 \mathrm{in}$.). For changing the catalyst, each converter is provided with a manway located at the top. The vessels are insulated to maintain the surface temperature below $60^{\circ} \mathrm{C}\left(140^{\circ} \mathrm{F}\right)$. The vessels are ASME code stamped for the following conditions.

Temperature $\quad 540^{\circ} \mathrm{C} \quad\left(1,000^{\circ} \mathrm{F}\right)$

Pressure $\quad 170 \mathrm{kPa} \quad(25 \mathrm{psig})$

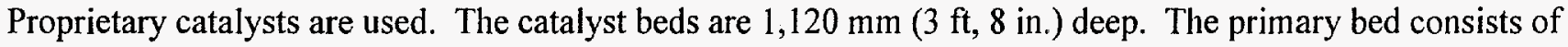
$890 \mathrm{~mm}$ ( $2 \mathrm{ft}, 11 \mathrm{in}$.) of $6 \mathrm{~mm}$ (1/4 in.) Raschig rings. The polishing bed is located beneath the primary bed and consists of $230 \mathrm{~mm}(9 \mathrm{in}$.) of $1.6 \mathrm{~mm}(1 / 16 \mathrm{in}$.) extrudate.

The ammonia reactant storage tank is a carbon steel right cylinder, $5,200 \mathrm{~mm}(17 \mathrm{ft})$ tall, $1,070 \mathrm{~mm}(3 \mathrm{ft}, 6$ in.) diameter with elliptical dished heads and a maximum working capacity of $3.8 \mathrm{~m}^{3}$ (1,000 gal.). It is located outof-doors so that any leakage can harmlessly disperse. The tank is painted for rust resistance. It was designed and code stamped for the following conditions.

Temperature $43^{\circ} \mathrm{C}$

$\left(110^{\circ} \mathrm{F}\right)$

Pressure

$1.7 \mathrm{MPa}$

(250 psig) 


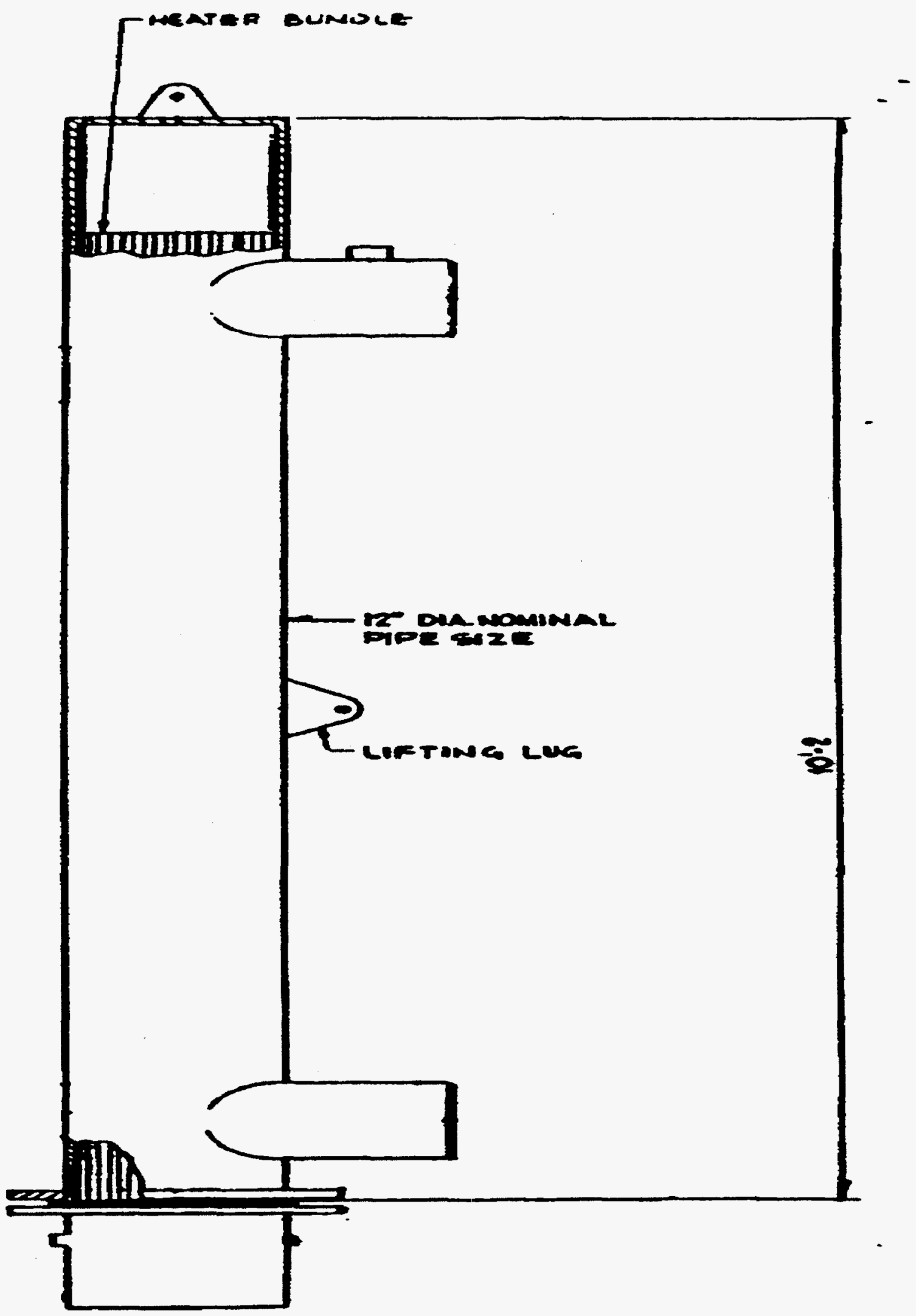

Figure 3.24-1. $\mathrm{NO}_{\mathrm{x}}$ Abatement System Preheater 


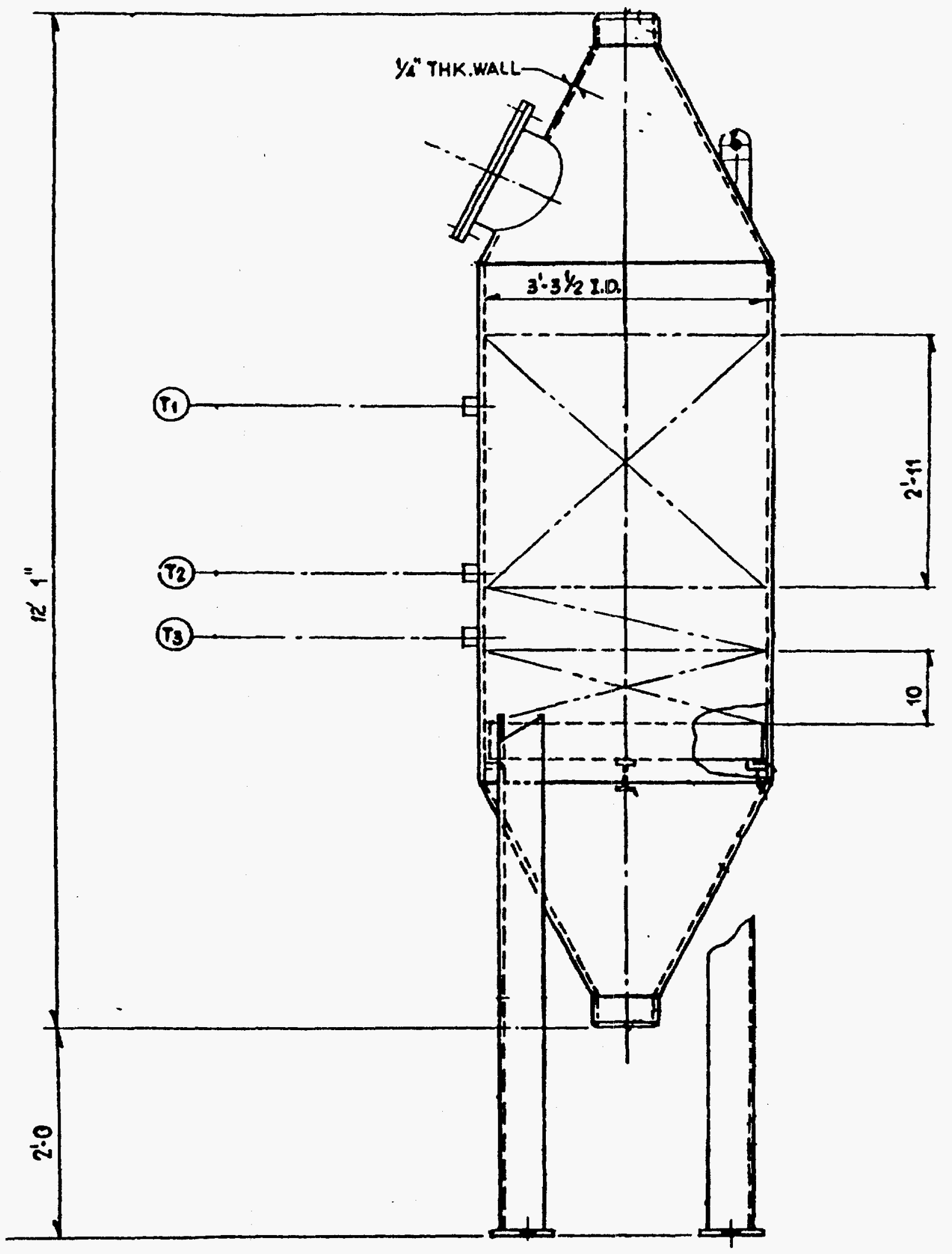

Figure 3.24-2. $\mathrm{NO}_{\mathrm{x}}$ Abatement System Catalytic Converter 


\subsection{CONCLUSIONS}

During the first three months of radioactive operation (July to October, 1996), which was the entire radioactive operating experience at the time this report was prepared, 1.3 million Curies of radioactivity were processed. The sustainability of the design glass production rate of $30 \mathrm{~kg} / \mathrm{h}\left(66 \mathrm{Ib}_{\mathrm{m}} / \mathrm{hr}\right)$ was demonstrated. A melter availability of $87 \%$ was realized while 36 canisters were filled with radioactive glass, welded closed, decontaminated, and transferred to interim storage. The off-gas equipment restricted the radionuclide releases to well below regulatory limits. $\mathrm{NO}_{\mathrm{x}}$ was also destroyed to emission levels below site regulatory limits.

Based upon the initial operating experience described above, one can conclude that the equipment installed in the Vitrification Facility at the West Valley Demonstration Project, as described in this report, performs as intended. 


\subsection{REFERENCES}

(1) 96th Congress, An Act to authorize the Department of Energy to carry out a high-level liquid nuclear waste management demonstration project at the Western New York Service Center in West Valley, New York, Public Law 96-368, October 1, 1980

(2) Hannum, W.H., Analysis of the Terminal Waste Form Selection for the West Valley Demonstration Project, WVDP-100, undated

(3) Chapman, C.C. and W.P. Drosjack, Vitrification Process Equipment Design for the West Valley Demonstration Project, Topical Report DOE/NE/44139-42, October 1988

(4) Skillern, C.G., Design Criteria: Vitrification of High-Level Wastes, WVNS-DC-022, Rev. 3, January 20, 1993

(5) Skillern, C.G., Facility Description: High-Level Waste Solidification Facilities, WVNS-FD-001, Rev. 3, December 13, 1995

(6) Schiffhauer, M.A., System Description: Sludge Mobilization System - HLW Transfer System, WVNS-SD-055, Rev. 0, January 17, 1995

(7) Drosjack, W.P., Design Criteria: Concentrator Feed Make-up Tank 63-V-001-N, WVNS-DC-033, December 15, 1986

(8) Carl, D.E., System Description: Primary Process System, WVNS-SD-631, Rev. 3, May 17, 1996

(9) Carl, D.E. et al., West Valley Demonstration Project Vitrification Process Equipment Functional and Checkout Testing of Systems (FACTS), Topical Report DOE/NE/44139-64, September 30, 1990

(10) Studd, M.G., System Description - Vitrification Facility Sampling, WVNS-SD-69A, Rev. 2, December 19, 1995

(16) Vance, R.F., System Description - Canister Decontamination System, WVNS-SD-63J, Rev. 3, December 28, 1995

(17) Meigs, R.A., Systems Description: In-Cell Remote Handling, Maintenance, and Viewing, WVNSSD-63K, Rev. 0, March 21, 1995 


\subsection{REFERENCES (continued)}

(18) Vance, R.F., System Description - Waste Header System, WVNS-SD-63G, Rev. 3, January 30, 1996

(19) Vance, R.F., System Description - Off-Gas \& Vessel Vent System, WVNS-SD-63H, Rev. 5, July 3, 1996

(20) Vance, R.F., The Integrated Melter Off-Gas Treatment Systems at the West Valley Demonstration Project, DOE/NE/44139-67, December 1991

(21) Vance, R.F., System Description - Ex-Cell Off-Gas System, WVNS-SD-64, Rev. 5, July 24, 1996 


\subsection{ACKNOWLEDGMENTS}

The information presented in this Topical Report reflects the work of many dedicated technical people. They are innumerable, and their contributions were necessary for the successful completion of the Vitrification Facility equipment described in this report. That the Facility successfully started processing high-level radioactive waste during July 1996 is to their credit.

The contributing authors typically functioned for prolonged periods of time in engineering positions allowing them to have significant influence on the final equipment configurations. In alphabetical order, Bernie Brill designed the canister grapple and served as the system engineer for the canister weld station. Dr. Dan Carl served as system engineer for the primary process that includes the concentrator feed make-up tank, the melter feed hold tank, the slurry-fed ceramic melter, and the canister turntable. Hardip Dhingra was responsible for the mechanical designs of the film cooler and the film cooler cleaner. Rick Meigs served as system engineer for the in-cell remote handling, maintenance and viewing systems, which include the crane and the transfer cart. Mark Studd served as system engineer for the sampling system, which includes the slurry sample system and the glass shard sample system, and also for the canister decontamination station. Rich Vance served as system engineer for the vessel vent and off-gas systems including the waste header, vessel ventilation equipment, submerged bed scrubber, mist eliminator, high-efficiency mist eliminators, filter preheaters, prefilters, reheaters, final HEPA filters, off-gas blowers, and $\mathrm{NO}_{\mathrm{x}}$ abatement equipment.

The system engineer for the sludge mobilization and transfer system, which includes the sludge mobilization pumps and transfer lines, was Mark Schiffhauer. His contributions were significant and he would have been a contributing author had he been available. 